\title{
Frequency, iteration and quantity: the semantics of expressions of frequent repetition in Russian and their relationship to aspect
}

\section{Фреквенция, итеративность и квантитативность: семантика выражений многократности в русском языке и их соотношение с видом глагола}

\section{Egbert Fortuin (Эхберт Фортейн)}

Published online: 17 July 2008

(C) The Author(s) 2008. This article is published with open access at Springerlink.com

\begin{abstract}
Аннотация Статья посвящена семантике выражений иасто, много раз и много. Эти слова могут использоваться как выражения многократности. Однако нельзя здесь говорить о тождестве значений. Часто трактуется как выражение неограниченной кратности с фреквентативным характером, а много раз как выражение ограниченной кратности с итеративным характером. Главное значение слова много-количество, также в тех контекстах, где оно обозначает многократность. Эти разные значения связаны с разными семантическими и синтаксическими свойствами, в том числе и с различиями в виде глагола.
\end{abstract}

\section{Introduction}

In Russian there are different forms which can express that a particular situation (event, state, process, etc.) is repeated a large number of times, namely [uacmo 'often' + verb], [много раз 'many times' + verb], and [много 'a lot/much' + verb]. The similarity in the meaning of these expressions is illustrated below: ${ }^{1}$

(1) Мы с женой часто ездим ${ }^{\mathrm{ipf}}$ в Репино под Петербургом [...].

(Известия, 2001.12.17)

'My wife and I often travel ${ }^{\text {inf }}$ to Repino close to Petersburg.'

\footnotetext{
${ }^{1}$ All the examples are taken from the Национальный Корпус Русского Языка (NKRJa) unless indicated otherwise. In the Russian examples and their English translations, I have indicated aspect with uppercase pf (perfective) and ipf (imperfective). As far as possible, I have tried to give literal translations of the Russian sentences.
}

I benefited greatly from discussions with Adrie Barentsen, Ronny Boogaart, Jenny Doetjes and Hans-Robert Mehlig. I would also like to thank my students Jörgen Moorlag and Renate Kikkert, who helped with the collection of the data.

E. Fortuin $(\bowtie)$

Universiteit Leiden, Faculteit der Letteren Slavische talen en culturen \& Ruslandkunde,

P.N. van Eyckhof 2, 1164/203a, 2300RA Leiden, The Netherlands

e-mail: E.Fortuin@let.leidenuniv.nl 
(2) Мы много раз ездили ${ }^{\mathrm{ipf}}$ по разным ущельям и местам.

(А. Микоян, Так было)

'We traveled ${ }^{\mathrm{ipf}}$ many times along different gorges and places.'

(3) За последние два года я много ездил ${ }^{\mathrm{ipf}}$ по регионам [...].

(Известия, 2001.08.17)

'In the last two years I have traveled ${ }^{\text {ipf }}$ to the regions a lot.'

To the best of my knowledge, no analyses exist which discuss both the similarities and the differences between иасто, много раз аnd много in Russian, or similar expressions in other languages. Furthermore, since some linguists argue that the meaning of expressions such as uacmo can be traced back to 'many times' (see Doetjes 2007), an analysis which explicitly addresses the difference in meaning between иасто and много раз may shed further light on the category of frequency expressions as such. The goal of this paper is to provide a semantic analysis of all three expressions of frequent repetition by looking specifically at the way in which these expressions function with respect to aspect. The general conclusion of my analysis is that although the three expressions of frequent repetition share particular semantic features, they also differ in some important aspects, and each conceptualize the idea of frequent repetition differently. I will argue that uacmo expresses high frequency, whereas много раз can better be analyzed as an expression of high iteration. The adverb много essentially expresses the idea of a large quantity, but can be interpreted as referring to several repeated situations (cf. Doetjes 2007). As I will show, these differences in conceptualization are connected to differences in aspectual use.

The paper is structured as follows. Section 2 analyzes the main differences in semantics between иасто, много раз аnd много. Section 3 describes how these expressions function with respect to aspect. In Sect. 4 a brief discussion is provided of how the meanings of the frequency expressions are related to the possibility of having a so-called relational reading. The conclusion is given in Sect. 5.

\section{The meanings of часто, много раз and много}

\subsection{The meaning of uacmo}

The adverb nacmo always occurs with a verb, or parts of speech with a quasi verbal meaning such as participles or gerunds (verbal adverbs). Yacmo expresses that the distance between the temporal intervals of a non-specified number of repeated situations is small, according to some contextually given standard. Because nacmo expresses that the number of occurrences of a repeated situation per time unit is high, it can be seen as a typical frequency expression (cf. Mehlig 1982; de Swart 1991).

In the literature (for references see, e.g., de Swart 1991, 282), it has been observed that often requires a regular distribution of situations over the time axis, and that this regularity induces cyclic meaning effects. In my view, this property of often or its Russian counterpart nacmo is due to the fact that these expressions abstract away from the idea of an individual occurrence of a situation. They therefore usually refer to occurrences that take place in a non-specified time span (e.g. the habitual statement in (1)), or a relatively large time span, which easily suggests the idea of a reoccurring (cyclic) repetition. Because of its cyclic character, uacmo can be seen as a typical frequency expression (cf. Mehlig 1982). However, in sentences with specific temporal modifications, the repetition may also take place in a relatively short time, cf. (4) and (5): 
(4) [Р]аботе его в этот день, по-видимому, суждено часто прерываться ${ }^{\text {ipf }}$. (Н. Лопатин, Вести из Ясной Поляны)

'Apparently, for some reason his work will be/is bound to be interrupted ${ }^{\text {ipf }}$ often that day.'

(5) Во время их разговора он часто вставал ${ }^{\mathrm{ipf}}$ и делал ${ }^{\mathrm{ipf}}$ несколько шагов по комнатке взад-вперед. (А. Фадеев, Молодая гвардия)

'During their conversation, he frequently [lit. often] stood up ${ }^{\mathrm{ipf}}$, and took ${ }^{\text {ipf }}$ some steps back and forth around the room.'

With respect to the time span in which the repeated situations occur, yacmo does not behave in the same way as its antonym редко ('rarely', 'seldom'). The adverb редко cannot be used with respect to a time span like a day, but requires a larger time span, for example a year, depending on what is considered a large temporal interval with respect to the particular situation:

(6) $\quad$ В тот год я редко выходил ${ }^{\mathrm{ipf}}$ из дома.

'That year I seldom/rarely left ${ }^{\text {ipf }}$ the house.'

The explanation for the difference between иасто and редко is probably that because редко expresses that there are relatively few occurrences of a particular situation, the presupposition is that the temporal distance between the occurrences is greater. Consequently, редко requires a larger time span than часто.

In Russian, the adverb uacmo also has a secondary meaning. In some sentences (often with an intensifier or reduplication (иасто-иасто), which has the same effect) it refers to multiple short events that occur in a sequence, and nacmo expresses something like 'in a quick succession'. This is typically the case with multiplicative verbs as in (7):

Продавец стоял с каменным лицом и часто-часто моргал ${ }^{\text {ipf }}$.

(О. Дивов, Выбраковка)

'The seller was standing with a set face and very quickly [lit. often] blinking his eyes ${ }^{\text {ipf }}$,

Multiplicatives express bundles of short events that occur in different series such as zamb $^{\text {ipf }}$ ('blink'), cmyчamb ipf ('knock'), etc. They have a semelfactive perfective counterpart, which expresses one instance of such a series of events-e.g. моргнуть ${ }^{\mathrm{pf}}$ ("blink one time'). Note, however, that this specific use of nacmo also occurs with verbs that are not strictly multiplicative, because they have no semelfactive counterpart. This is for example the case in (8) with биться ('beat'):

(8) [C]ердце билось ${ }^{\text {iff }}$ часто-часто, в унисон колокольному звону.

(Т. Тронина, Русалка для интимных встреч)

'The heart was beating ${ }^{\text {ipf }}$ very fast [lit. often-often], in unison with the ringing of the bells.'

The use of yacmo under discussion is not confined to imperfective verbs, but also occurs with perfective verbs with the delimitative prefix no-, or the ingressive prefix $3 a_{-}$, that are derived from multiplicative or semi-multiplicative verbs:

(9) Умрихин вздохнул, часто-часто поморгал ${ }^{\mathrm{pf}}$ и отвернулся от огня, будто уберегая лицо от жара. (М. Бубеннов, Белая береза)

'Umrixin sighed once, very quickly [lit. often-often] blinked his eyes ${ }^{\mathrm{pf}}$ and moved away from the fire, as if he wanted to protect his face from the heat.' 
(10) В ту же секунду Катя как-то странно, слишком часто задышала ${ }^{\text {pf }}$ и швырнула в мою сторону какой-то предмет. (Д. Донцова, Доллары царя Гороха) 'In that very second, for some strange reason, Katja began to breathe ${ }^{\text {pf }}$ too quickly [lit. often] and threw an object in my direction.'

A similar use also occurs when a semelfactive verb is combined with an expression like несколько раз ('a couple of times'):

(11) Под моим взглядом она перекатила голову по подушке и несколько раз часто вздохнула ${ }^{\text {pf }}$ во сне. (А. Кабаков, Последний герой)

'While I was watching her, she rolled her head back and forth on the pillow and sighed $^{\mathrm{pf}}$ quickly [lit. often] a few times while sleeping.'

Furthermore, the meaning of 'in a quick succession' occurs in sentences with (imperfective) auxiliaries with an ingressive meaning. In such sentences the infinitive can also express a situation which is normally not multiplicative, as is shown by (13) with the verb yмирать ${ }^{\text {ipf }}$ ('die'):

(12) И только плечи его начинали ${ }^{\text {ipf }}$ часто вздрагивать $^{\text {ipf }}$. (Октябрь, 2003) 'And only his shoulders started ${ }^{\text {ipf }}$ to shudder $^{\text {ipf }}$ regularly/quickly [lit. often].'

(13) Где-то посередине лета наступало время, когда люди в Яблоновке начинали $^{\text {ipf }}$ часто умирать ${ }^{\text {ipf }}$ и каждый день были похороны. (Ю. Петкевич, Явление ангела)

'Sometime in the middle of summer, a time came when the people in Jablonovka started $^{\text {ipf }}$ to die $^{\text {ipf }}$ rapidly [lit. often] and every day there were burials.'

The ingressive auxiliary enables the reading of uacmo as 'in a quick succession' in sentences like (13) because it focuses on a specific moment where a period of quickly repeated situations begins, thus creating the idea of a series of events which belong together.

\subsection{1 Часто with the interrogative как}

At this point, I would like to make some remarks about the use of nacmo when it occurs with the interrogative как ('how'). In questions with как иасто and an imperfective present tense, the speaker is interested in the frequency of the occurrence of a particular situation, or to put it differently, in someone's habit, for example:

(14) Как часто вы читаете газету?-Несколько раз в неделю.

'How often do you read the newspaper?'-'A few times a week.'

In answering the question in (14), the addressee may refer to a specific number of times, as long as the time span in which the repetition that occurs is mentioned (here: в неделю 'a week'):

(15) Как часто вы читаете газету?_*Несколько раз.

'How often do you read the newspaper?'-“*A few times.'

Sentence (15) is not acceptable because the speaker is not interested in the absolute number of occurrences of the situation, but in the question of whether the occurrence of the situation can be seen as being frequent or not. Put differently, the answer expected from 
the addressee must provide information to determine whether the distance between the temporal intervals is small or not. The standard according to which this is measured is provided by the time span. This also explains why the answer кажәый день ('every day') is acceptable as well:

(16) Как часто вы читаете газету?-Каждый день.

'How often do you read the newspaper?'-'Every day.'

The expression кажәый день is in full accordance with the meaning of иасто in (16) because this expression provides the hearer with information to determine whether the distance between the temporal intervals is small or not. It should be noted that the tense of the verb plays an important role here. In sentences with a past tense form, uacmo can in fact be used in questions where the speaker is interested in the absolute number of occurrences:

(17) Как часто это случалось?-Думаю, три раза.

(lib.ru/INOFANT/SERLING/solnce.txt; 05-27-2008)

'How often did that happen?'-'I think three times.'

In sentences like these, nacmo functions as the unmarked expression of time, similar in meaning to сколько раз ('how many times'). Note, however, that сколько раз and как иасто are not synonymous in all contexts. In questions with сколько раз the speaker is always interested in the absolute number of occurrences of a situation. Because of this, it is not used in sentences where the speaker is interested in a particular habit or frequency (with a present tense):

(18) ? Сколько раз вы читаете газету?

[question about the habit of a person]

'How many times do you read the newspaper?'

However, question (18) would be acceptable if reference were made to a time span such as в неделю. Similarly, the answer to the question with a past tense in (19) is slightly marked because it does not provide information about the absolute number of times (Mehlig 1982, 133):

(19) Сколько раз вы читали газеты?-?Каждый день.

'How many times did you read the newspaper?'- ' Every day.'

To conclude, uacmo can be regarded as a typical frequency expression, and it functions as such in questions with the interrogative как. In some sentences with a past tense, however, как иасто is similar in meaning to сколько раз.

\subsection{The meaning of много раз}

I will now turn to the meaning of много раз. The semantics of много раз can be compositionally derived from its components много ('much') and раз ('time', 'occurrence'). It expresses that the number of repeated situations is higher than some contextually given standard. It should be mentioned here that my analysis differs from the one given by Doetjes (2007, 694, 701), who argues that French souvent ('often') can essentially be paraphrased with 'many times'. Doetjes $(2007,686,701,715)$ also suggests that this semantic descrip- 
tion can be applied cross-linguistically. ${ }^{2}$ A problematic feature of this analysis, at least for Russian, is that it cannot explain the difference in meaning between иасто and много раз. Много раз аnd иасто both express that the number of repeated situations is higher than some contextually given standard. As such, много раз shares features with frequency expressions. However, the meaning of иасто differs from that of много раз since иасто abstracts away from the idea of an individual occurrence of a situation. The adverb uacmo can therefore be seen as an expression of неограниченная кратность, that is, open or non-quantifiable repetition (cf. Mehlig 1982, 134), whereas много раз is an example of the class of ограниченная кратность, that is, closed or quantifiable repetition. Following Mehlig (1982) and de Swart (1991), I will use the term 'iteration' to refer to this type of repetition. It should be stressed that in the case of много раз the iteration is conceptualized as indefinite. This means that it refers to specific individual occurrences of a situation (through раз) without giving information about the absolute number of situations (for the term 'indefinite' see Kučera and Trnka 1975, 67, and Mehlig 1982, 134). As such, it differs from expressions such as три раза ('three times').

Because много раз does not abstract away from the idea of 'time', it may refer to different situations that take place in a relatively short time interval, without explicit reference to this time span. Note that this difference in meaning is not a coincidental property of Russian, but occurs in other languages as well, for example English, as can be illustrated with the following example, where many times cannot be replaced by often:

(20) a. They all shook hands many times.

[at a particular occasion]

b. They often shook hands.

[on different occasions]

An important difference between many times and often is that many times does not refer to a specific (reoccurring) habit, but to the repetition of a large number of situations. This specific property of 'many times' probably also explains why the French beaucoup de fois ('many times') does not occur with the imparfait (cf. Doetjes 2007, 694, note 8). Also note that the interpretation of a regular distribution of situations over the time axis, which is part of most sentences with uacmo, is not a necessary interpretation of sentences with много раз or many times. Although the idea of a regular distribution is also strongly suggested by много раз оr many times, it is possible to say that someone played the piano many times last year, but that the repetition had an irregular character.

If we turn to Russian, this difference in meaning between иасто and много раз is also reflected in the tense of the verbs with which the expressions occur. Table 1 lists the tense of the verbs combined with the expressions of frequent repetition from a survey of 100 randomly selected sentences of the Национальный корпус русского языка ('National corpus of the Russian language'; henceforth NKRJa).

Table 1 shows that there is a significant difference between иасто and много раз. Whereas иасто typically refers to an event in the present as in (1), много раз typically refers to events in the past as in (2). This difference can be linked to the semantic difference

\footnotetext{
${ }^{2}$ Doetjes $(2007,701)$ also provides some interesting morphological evidence to support her claim. She notices that in many languages expressions of frequency contain morphological material that corresponds to something like fois or times, or can be derived from such expressions (e.g. English oftentimes). Furthermore, some expressions that contain a time operator cannot be seen as instances of closed repetition, e.g. French quelquefois ('sometimes'), which contains the word fois ('times'). In my view, data such as these do indeed point to the close relation between expressions like иасто and много раз. However, what the actual function of the reference to 'time' is, differs from language to language, and from expression to expression.
} 
Table 1 The use of tense with иасто, много раз and много

\begin{tabular}{lllllll}
\hline & Present & Past & Future & Infinitive & Imperative & Total $^{3}$ \\
\hline часто & $70(75 \%)$ & 18 & & 5 & & 93 \\
много раз & 8 & $82(92 \%)$ & 3 & 6 & & 99 \\
много & 30 & $57(55 \%)$ & 15 & 1 & 1 & 104 \\
\hline
\end{tabular}

between these expressions observed earlier. Since много раз refers to specific individual events, it is typically used in sentences where the occurrence of the situations has already been established-usually, if the situation has occurred in the past. Such a strong association with the past tense is absent with uacmo. Because uacmo abstracts away from specific occurrences of a situation, it is often used in general, generic or habitual statements. Such statements are typically expressed in the present tense:

(21) Я часто меняю ${ }^{\mathrm{ipf}}$ планы в последнюю минуту. (Экран и сцена, 2004.05.06) 'I often change ${ }^{\text {inf }}$ plans at the last minute.'

In the same survey from the NKRJa as given in Table 1, the meaning of the verbs where examined as well (see Appendices A, B and C). Appendix A shows that in the examined examples verbs that are attested more than twice with часто are бывать ('(happen to) be'), встречаться ('meet'), менять(ся) ('change'), and делать ('do'). Appendix B shows that verbs that were attested more than twice with много раз are говорить ('speak'), делать(ся) ('do'), повторять ('repeat'), приходить ('come'), писать(ся) ('write'), and nытаться ('try'). Table 2 indicates the number of occurrences of these verbs with yacmo or много раз in the NKRJa based on the search term [часто/много раз + verb] in the whole corpus.

Table 2 shows that verbs that occur with часто can also occur with много раз, and vice versa, but that that there are also differences between иасто and много раз with respect to the occurrence of particular verbs. Note, for example, that $29 \%$ of the sentences with nытаться in Table 2 occur with много раз, whereas with the verb бывать it is only $2 \%$. This can be explained in terms of the meaning of both verbs. Whereas nытаться can easily be used in contexts where it refers to a specific concrete event, the verb бывать can easily be associated with an ongoing situation, which does not take place at one specific moment only. In order to test this hypothesis, further statistical analysis is necessary. This goes, however, beyond the scope of the present analysis.

\subsection{The meaning of много}

I will now proceed to the analysis of много. This adverb expresses that the quantity of the contextually given entity to which it is applied is more than some (contextually given) standard. As I already remarked, много can be used with verbs, as was illustrated with (3). In this example, the adverb is applied to different individual events which are taken together

\footnotetext{
${ }^{3}$ In the case of uacmo, 6 examples with a past participle and one example with a relative clause were not considered (the few examples with a present passive or active participle were counted as examples of the present tense). In the case of много раз, 3 participles (with the past tense of быть) were not considered. Besides this, there were two sentences which contained two verbs. In the case of много, there were 4 sentences with two verbs.
} 
Table 2 Number of verbs with иасто and много раз 4

\begin{tabular}{lll}
\hline & иасто & много раз \\
\hline бывать '(happen to) be' & 2002 & $41(2 \%)$ \\
встречаться 'meet' & 848 & $15(2 \%)$ \\
делать 'do' & 178 & $5(3 \%)$ \\
менять 'change' & 208 & $10(5 \%)$ \\
писать 'write' & 129 & $12(8 \%)$ \\
видеть 'see' & 681 & $71(9 \%)$ \\
повторять 'repeat' & 340 & $51(13 \%)$ \\
говорить 'speak' & 404 & $82(17 \%)$ \\
пьлтаться 'try' & 22 & $9(29 \%)$ \\
\hline
\end{tabular}

in order to evaluate the totality of events as being a large amount. In this case the idea of a large quantity is intrinsically connected to the idea of repetition or frequency. This is because we interpret the idea of a large quantity here as the result of the collection of many different travel occurrences. At the same time the duration of each individual travel event can play a part as well. A similar interpretation occurs in the following sentence:

(22) Да, я в детстве много сидела ${ }^{\text {ipf }}$ на голом цементном полу зимой [...].

(С. Осипов, Страсти по Фоме. Книга третья. Книга Перемен)

'Yes, in my childhood I sat ${ }^{\text {ipf }}$ on the bare cement floor during winter a lot.'

With the verb cuдеmь ('sit'), it is difficult to arrive at an interpretation in which the verb refers to one individual event. Because of this сидеть много usually refers to the number of individual sitting occurrences (which may each be long), and cannot refer to the large amount of sitting in one individual sitting occurrence. For this, other adverbs have to be used (e.g. долго 'long'), cf. (23):

(23) Татьяна Петровна долго сидела ${ }^{\mathrm{ipf}}$ у стола [...]. (К. Паустовский, Снег) 'Tatjana Petrovna sat ${ }^{\mathrm{ipf}}$ at the table for a long time.'

Note, however, that the idea of repetition is not part of every sentence with много. In the following sentences the time span in which the event occurs is relatively short:

(24) Сегодня днем много гуляли ${ }^{\mathrm{ipf}}$. (В. Брагин, В стране дремучих трав) 'We walked ${ }^{\text {inf }}$ a lot during the day today.'

In this case, the walking can be interpreted as having taken place the whole day. It may have consisted of different instances, or one big instance. The use of много only expresses that the amount of walking is considerable (cf. Doetjes 2007, 686, for French beaucoup).

As can be seen from Table 1, the survey of 100 sentences in the NKRJa shows that with regard to tense, много exhibits similarities both with иасто and много раз. There is, however, a clear difference between много and the two other expressions of frequent

\footnotetext{
${ }^{4}$ For each verb I have indicated the percentage of sentences with много раз of the total number of instances (много раз and иасто together). 
repetition with regard to the verbs. The results of the survey of 100 examples from the NKRJa are given in the appendix. In this survey the most frequently attested verbs are 'work' (работать, заниматься, трудиться), together $29 \%$ of all the examples and 'think' (думать, размышлять), which constitute together about $10 \%$ of all the examples. Another frequently attested verb is смеяться ('laugh'). What all these verbs have in common is that they can easily be associated with a particular quantity ('much work', 'much thought', 'much laughter'). Note, furthermore, that in many cases, a relation between много as an object of the verb, and много as a modifier of the verb can be perceived. Take for example the verb разговаривать ('talk'), which has no accusative object valence, but which may be used with an oblique object with the preposition $o$ ('about'). If applied to this verb, много can express both the long duration of one individual talking situation ('there was a lot of talking'), and the content of the speaking in this situation, which is evaluated as a lot ('a lot of things were said'):

(25) Санин разговаривал ${ }^{\mathrm{inf}}$ много, по-вчерашнему, но не о России и не о русской жизни. (Тургенев, Вешние воды)

'Sanin talked ${ }^{\text {ipf }}$ a lot, as in the old days, but not about Russia and the Russian life.'

Cases like these are close to uses where много functions as the object of the verb, and does not modify the situation itself:

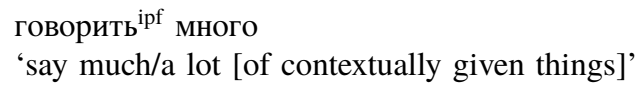

Note that the interpretation of много as an object of the verb is obligatory in the case of transitive verbs. This is for example the case in the following sentences with покупать ('buy') and видеть ('see'):

\section{Я много покупал ${ }^{\mathrm{ipf}}$. \\ 'I bought ${ }^{\text {ipf }}$ a lot [of things].'}

(28) Он много видел ${ }^{\mathrm{ipf}}$ и пережил ${ }^{\mathrm{pf}}$. (Мурзилка, №1, 2003)

'He saw ${ }^{\text {ipf }}$ and survived ${ }^{\mathrm{pf}}$ a lot [of things].'

The interpretation where много modifies the situation expressed by the verb ('many buy/see occurrences') is extensionally close to cases where много functions as an object. Sometimes the two cases are hard to distinguish. Nevertheless, the most natural interpretation is that the speaker wants to convey that the number of objects bought or seen is great, rather than that the total amount of realizations of buying or seeing is large (for example 'I have spent much time in the shop').

Note, furthermore, that in sentences like (27) it is in fact not possible to use a nominal accusative object (* Я много покупал такие книги, lit. 'I bought such books a lot/much'). It is possible to use a noun, but in that case много modifies the noun, which has to occur in the genitive ( Я много покупал таких книг, lit. 'I bought many of such books'). This shows that the use of Russian много is not identical to English a lot, which can be used as an expression of frequency with transitive verbs.

The strong tendency to be interpreted as an object may also explain some other properties of много. Doetjes $(2007,716)$ provides a cross-linguistic sample study, showing that in none of the languages studied by her (Hungarian, Dutch, Moroccan Arabic and Indonesian) sentences with forms expressing 'much/a lot' can occur with quantificational modifications like three kilogram of $X$, whereas the same use is possible with operators like often. Russian много adheres to this cross-linguistic pattern: 
(29) *Петр много покупал ${ }^{\mathrm{ipf}}$ три килограмма апельсинов.

lit. 'Peter bought ${ }^{\mathrm{ipf}}$ much three kilograms of oranges.'

(30) Петр часто покупал ${ }^{\mathrm{ipf}}$ три килограмма апельсинов.

lit. 'Peter often bought ${ }^{\mathrm{ipf}}$ three kilograms of oranges.'

In explaining this difference in use, the following should be taken into account. First, as I indicated above, with transitive verbs, много is almost exclusively interpreted as an object, in contrast to часто (or много раз) which cannot function as an object. This property explains why sentences like (29) are not acceptable. Second, the quantifier много either quantifies over one event, as in (24), or conceptualizes different situations as one set in order to quantify over them, as in (3). Because of this, много abstracts away from individual properties of individual situations within that set. This also explains why sentences like Я много играю на рояле примерно иас (lit. 'I play the piano for about an hour a lot'), are marked as well. The same phenomenon can probably also account for some properties of English $a$ lot. This expression can be used to refer to repeated situations with a transitive verb if the object of the verb has a more generic character, for example I buy such items a lot. In sentences where the object has a more specific character, the use of a lot is less acceptable, for example ? I buy three kilograms of oranges a lot.

With regard to (29) it can be concluded that if the speaker wants to express that he bought three kilograms of oranges several times, and that the frequency of this buying is considerable, иасто оr много раз would be the most optimal candidates to express this meaning, not много. It should be noted here that if the speaker wants to express that there is a large amount of objects, and the frequency of buying is irrelevant, he can use another verb, namely накупить ('buy a lot'). With this verb the idea of a high quantity is expressed by the prefix $\mathrm{Ha}^{-}$:

(31) Вооруженный всеми этими знаниями я накупил ${ }^{\mathrm{pf}}$ двадцать килограмм всяких газет и журналов.

(olius.ru/artpaper/humour/a/8678.7.html)

'Armed with all that knowledge, I bought ${ }^{\mathrm{pf}}$ [lit. bought a lot] 20 kilograms of newspapers and journals.'

Finally, it should be noted that много can also be used as an intensifier:

(32) Я искренно был тронут и сказал несколько теплых слов в честь монголов, и главным образом в честь Гэндэна, который $1 / 2$ года тому назад очень много помог ${ }^{\mathrm{pf}}$ мне в Сайн-н[оин]-курэ. (П. К. Козлов, Географический дневник Тибетской экспедиции 1923-1926 гг., № 5)

'I was sincerely touched and said a few warm words in honor of the Mongols, and primarily in honor of Genden, who half a year ago helped ${ }^{\mathrm{pf}}$ me very much in Sajn-n[oin]-kure.'

Such sentences are more typical of the nineteenth century. See Fortuin (to appear) for an analysis.

In Sect. 2, I have given a semantic analysis of the three expressions of frequent repetition. The main semantic properties of these expressions are summarised in Table 3.

The similarities and differences between иасто, много раз and много are further underlined by their aspectual behavior. In the next section, I will discuss the interaction of the meanings of these expressions and aspect in some detail. 
Table 3 Semantic properties of иасто, много раз and много

\begin{tabular}{|c|c|c|c|c|}
\hline & Meaning & Frequent repetition & $\begin{array}{l}\text { Explicit reference to } \\
\text { specific occurrence } \\
\text { ('time') }\end{array}$ & $\begin{array}{l}\text { Explicit reference } \\
\text { to quantification }\end{array}$ \\
\hline \multirow[t]{2}{*}{ иасто $\mathrm{X}$} & $\begin{array}{l}\text { the distance between } \\
\text { temporal intervals of } \\
\text { a non-specified num- } \\
\text { ber of situations } X \text { is } \\
\text { small (high frequency) }\end{array}$ & yes & $\begin{array}{l}\text { no (abstraction from } \\
\text { the idea of a specific } \\
\text { occurrence) }\end{array}$ & no \\
\hline & $\begin{array}{l}\text { secondary meaning: } \\
\text { the different situations } \\
\text { occur in a quick } \\
\text { sequence }\end{array}$ & & & \\
\hline много раз $\mathrm{X}$ & $\begin{array}{l}\text { the number of occur- } \\
\text { rences of a situation } \mathrm{X} \\
\text { is large (high iteration) }\end{array}$ & yes & yes & yes \\
\hline много $\mathrm{X}$ & $\begin{array}{l}\text { situation } X \text { is associ- } \\
\text { ated with a big quan- } \\
\text { tity }\end{array}$ & $\begin{array}{l}\text { implicit in contexts } \\
\text { where the idea of } \\
\text { quantity is associ- } \\
\text { ated with multiple } \\
\text { occurrences }\end{array}$ & $\begin{array}{l}\text { no (the focus is on } \\
\text { the idea of quantifi- } \\
\text { cation) }\end{array}$ & yes \\
\hline
\end{tabular}

\section{Aspectual behavior of иасто, много раз and много}

\subsection{Aspectual behavior of uacmo}

\subsubsection{The relation between часто and the imperfective}

As already mentioned, sentences with uacmo belong to the class of so-called open repetition. This means that the adverb does not refer to a specific, countable number of occurrences. In Russian, the class of open repetition strongly favours the imperfective aspect, the so-called неограниченно-кратное значение 'unbounded multiple meaning' of the imperfective aspect. This can be illustrated by my survey of 100 sentences with uacmo from the NKRJa, which only contain examples of the imperfective past and present tense. The explanation for the use of the imperfective aspect is that even in the case of terminative (telic) situations, the repetition of the situation means that the idea of change is relegated to the background, and the focus is on the idea of constancy. ${ }^{5}$ This can be illustrated by picturing a single perfective situation like написать письмо 'write a letter' as in Fig. 1 (see Barentsen 1995, for a detailed analysis).

The repetition of an unspecified number of such realized terminative situations can be graphically depicted as in Fig. 2, where the idea of change is relegated to the background.

Nevertheless, the use of the perfective is not fully excluded with uacmo. To what extent the use of the perfective is possible depends on the tense and mood of the verb, and the

\footnotetext{
${ }^{5}$ In this paper, I will use the term 'terminative' in the broad sense of the word, according to the tradition of scholars like Maslov and Bondarko (see Barentsen 1995, 4-5, for a brief critical discussion of the term предельность and references). According to this definition, every perfective verb expresses a terminative situation, including delimitative verbs. Furthermore, imperfective verbs can also express a terminative situation, if the meaning expressed by the verb is associated with the idea of a boundary. This is for example the case with verbs like писать письмо ('write a letter') or приходить ('arrive').
} 
Figure 1 Perfective aspect

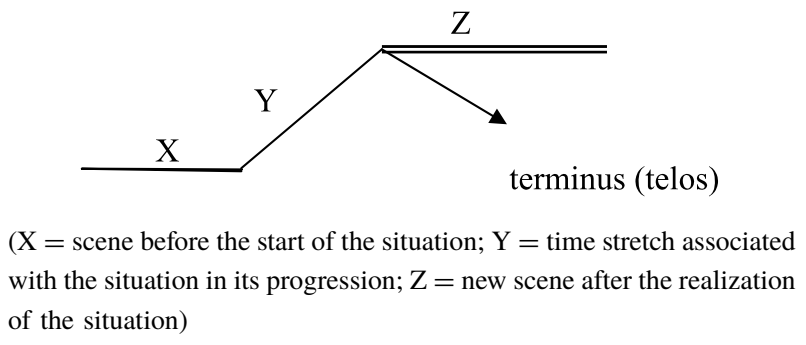

Figure 2 Repetition of a non-specified number of

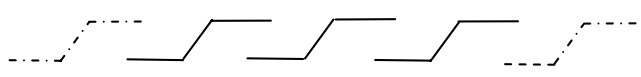
terminative situations

syntactic context in which the verb is used. Below, I will discuss contexts with a present tense, infinitive and past tense respectively.

\subsubsection{Aspectual behavior of часто: sentences with a perfective present}

Let us first discuss the perfective present tense, which, in Russian, is used as a perfective future tense. As is described in the literature (e.g. Bondarko 1971; Mehlig 1982), the use of the perfective present is possible with adverbs such as uacmo, if the perfective is interpreted as a case of наглядно-примерное значение ('graphic-illustrative meaning'). In such sentences the context refers to repeated events, but the perfective picks out one instance of such an event to present it as a typical example. Examples of this use can be attested in the NKRJa and on the internet, where the perfective suggests the potentiality for the situation to be realized:

(33) Чеснок часто поможет ${ }^{\mathrm{pf}}$ там, где бессильны современные лекарства. (azy.ru/catalog/product_info.php?products_id=3399; 05-27-2008)

'Garlic often helps ${ }^{\mathrm{pf}}$, where modern medication can't.'

(34) Нынче не так уж часто встретишь ${ }^{\text {pf }}$ человека с абсолютно здоровой щитовидной железой. (Сельская новь, 2003)

'Today you don't often meet ${ }^{\mathrm{pf}}$ a person with a fully healthy thyroid gland.'

In these sentences uacmo does not refer to a specific future period where the situation is repeated a non-specified number of times. If that were the case, the non-specified number of repeated situations would create the idea of a homogenous state, which requires the imperfective in Russian. Instead, what these sentences express is that often a specific situation is or can be fully realized. A similar use can also occur when the verb is an infinitive:

Часто описать ${ }^{p f}$ свой практический опыт [...] намного сложнее, чем что-то смастерить или воплотить на сцене. (Народное творчество, 2004)

'It's often the case that describing ${ }^{\mathrm{pf}}$ [lit. to describe $\mathrm{eff}^{\mathrm{pf}}$ often] your hands-on experience is much more difficult than working or personifying someone on the stage.'

Here, nacmo does not apply to оnисать ('describe often'), but has scope over the whole sentence ('it is often the case that'). Like the graphic-illustrative meaning of the perfective, as in (33), this construction has a semi-conditional meaning ("it is often the case that if 
you do $\mathrm{X}, \mathrm{Y}$ is the case'). Sentences like these are therefore reminiscent of the so-called relational use of uacmo, which will be discussed in Sect. $4 .^{6}$

\subsubsection{Aspectual behavior of часто: sentences with a perfective infinitive}

A perfective infinitive is possible if the main verb of the sentence is imperfective. This is for example the case in (37), where uacmo applies to, or has scope over, the imperfective past tense verb заходила in combination with the infinitive. In such sentences the perfective infinitive is triggered by the syntactic context, more specifically the use of an auxiliary requiring a perfective infinitive. In (36) the perfective aspect is triggered by можно ('can'), which can only express possibility (instead of permission) with a perfective infinitive, whereas in (37) the verb заходить triggers a perfective because it expresses a situation which is directed at the realization of the infinitive situation ('come to see'):

(36) Их можно было ${ }^{\text {ipf }}$ часто увидеть ${ }^{\text {pf }}$ вместе. (Октябрь, 2001)

'One could ${ }^{\text {ipf }}$ often $^{\text {see }}{ }^{\text {pf }}$ them together.'

(37) Если бы я [...] не заходила ${ }^{\text {ipf }}$ бы часто посмотреть ${ }^{p f}$, так и не увидела бы чудо это. (Форум на eva.ru, 2005)

'If I had not come ${ }^{\text {ipf }}$ to see $^{\text {pf }}$ it often, I would not have seen that miracle.'

\subsubsection{Aspectual behavior of часто: sentences with a past tense}

I will now turn to the past tense. As noted in the literature, in the past tense the use of the imperfective is obligatory with uacmo (e.g. Mehlig 1982, 134). An example of a past tense is given in (38):

(38) Как часто вспоминала ${ }^{\text {ipf }}$ я эти слова! (С. Спивакова, Не всё) 'How often I remembered ${ }^{\text {ipf }}$ those words!'

As I already mentioned, the use of the imperfective aspect points to a conceptualization where the repetition of a non-specified number of situations has the character of a constant flow of situations, without focusing on the boundaries. This character of duration and homogeneity is typical of the imperfective aspect, in contrast to the perfective aspect, which focuses on the boundary of a situation, for example because the situation occurs as a part of a chain of events, or because the speaker focuses on the effect of the realization of the situation at a particular vantage point. ${ }^{7}$ Although the imperfective is indeed obligatory

\footnotetext{
${ }^{6}$ In the NKRJa very few examples were attested with a perfective verb in combination with peдко, the antonym of uacmo:

Редко провёл ${ }^{\mathrm{pf}}$ я несколько дней [...] так приятно [...].

(Л. Н. Толстой, Отрочество)

'Rarely I have spent ${ }^{\text {pf }}$ a number of days so well.'

A similar example was found with повезти ('be lucky'). Apparently, the scope of редко overrules the strong preference for the imperfective aspect here. Sentences like these are extremely rare, and presumably not accepted by all speakers of Russian.

${ }^{7}$ The strong correlation between open repetition and the imperfective aspect is a property of Russian (or more generally East Slavic), which is not present in some other Slavic languages, especially Czech, Slovak and Slovene, but also Serbian-Croatian (see, e.g., Dickey 2000, 49-94). Dickey (2000) suggests that this difference has to do with the feature of 'temporal definiteness' which is part of the Russian perfective, but is absent in Czech, Slovak and Slovene, and to a lesser extent in Bosnian-Croatian-Serbian (cf. Barentsen's 1995 feature of sequential connection).
} 
in almost all past tense contexts, the data from the NKRJa show that there are two contexts which do in fact allow for a perfective:

(i) Sentences where uacmo is (also) applied to (has scope over) the infinitive

(ii) Sentences where uacmo is used in its secondary meaning of 'in quick succession'

First, the perfective aspect is used with the auxiliaries cmamb or начаmь (both mean 'begin' or 'start'), when they occur with an imperfective infinitive:

(39) С этого дня я часто стал ${ }^{\text {pf }}$ бывать ${ }^{\text {ipf }}$ у Василия Ивановича.

(В. Давыдов, Театр моей мечты)

'From that day on I started ${ }^{\mathrm{pf}}$ visiting $^{\text {ipf }}$ Vasilij Ivanovič regularly [lit. often].'

(40) Начали ${ }^{\mathrm{pf}}$ часто меняться ${ }^{\mathrm{ipf}}$ секретари, но уж ни одного не оказалось Романову соответствующим, никто не мог прочно занять за многие годы им обогретого места. (Новый Мир, № 2, 1999)

'They started $^{\mathrm{pf}}$ replacing ${ }^{\mathrm{ipf}}$ the secretaries regularly [lit. often], but since not one of them appeared to suit Romanov, none of them could firmly hold on to the position he had acquired.'

In such sentences uacmo applies to the infinitival situation, and the perfective auxiliary stresses that the period of repeated situations has begun. Such sentences differ from examples with an imperfective auxiliary, where the focus is on the onset of a period of repeated situations:

(41) Толкин очень часто начинал ${ }^{\text {ipf }}$ писать ${ }^{\text {ipf }}$ и очень редко заканчивал начатое. (Домовой, 2002.05.04)

'Tolkin very often started ${ }^{\text {inf }}$ to write ${ }^{\text {ipf }}$ and very rarely finished what he started.'

A similar explanation can be given for the use of some perfective auxiliaries that occur with imperfective infinitives, most notably the modal auxiliaries привыкнуть ('be used to') and прийтись ('have to', 'must'): ${ }^{8}$

(42) И так же любила их дочь, и привыкла ${ }^{\text {pf }}$ писать $^{\text {ipf }}$ им часто и подробно о каждом своём переживании.

(А. Солженицын, В круге первом, т. 1, гл. 26-51)

'And their daughter loved them too, and she got used ${ }^{\text {pf }}$ to write ${ }^{\text {ipf }}$ them often and in detail about all her experiences.'

${ }^{8}$ Two examples were attested that could not be categorized as belonging to either one of the context types:

(i) Этот дворец часто назвали ${ }^{\mathrm{pf}}$ Посольским домом [...]. (Т. Базарова, План петровского Петербурга. Источниковедческое исследование)

'This palace has often been called ${ }^{\text {pf }}$ the Ambassador's house.'

(ii) Последнее время они часто изменились ${ }^{\mathrm{pf}}$. (Беседа с социологом о переписи населения, 9, Владивосток // (2001.11.15))

'Lately, they have often been changed ${ }^{\mathrm{pf}}$.'

These sentences are probably not considered acceptable by most speakers of Russian. It should be noted, though, that the phrase иасто назвали оccurs on the Internet as well (search Google 23 January 2008: 29 times). Furthermore, the same verb is also attested in the perfective with много раз in the NKRJa. This suggests that the possibility of using a perfective here is connected to the meaning of назвать. Note, for example, that this use is close in meaning to a past passive participle, which can occur with the perfective if it is combined with иасто: иасто названный ('often called'). 
(43) Очень часто пришлось ${ }^{\text {pf }}$ нам вспоминать ${ }^{\text {ipf }}$ потом эту фотографию.

(В. Сидур, Памятник современному состоянию)

'We often had ${ }^{\text {pf }}$ to remember ${ }^{\text {ipf }}$ that photograph afterwards.'

In sentences with привыкнуть as in (42), иасто applies to the imperfective infinitive, and not to the past tense verb. In these sentences, the perfective past tense is used to stress that the habit of doing something is still valid at some vantage point. Here, the use of the imperfective counterpart (привыкала) would in fact be unacceptable, because this would suggest that the subject was attempting to get used to writing many times.

The explanation for the sentences with прийтись as in (43) is rather more complicated, because here it is less evident that uacmo applies to the infinitival situation only, and not to the state expressed by the auxiliary. One could argue that the necessity to do something occurs at different occasions. Furthermore, in contrast to (42), the use of an imperfective past tense auxiliary with an imperfective infinitive is not excluded, cf. (44):

(44) Ему часто приходилось ${ }^{\text {ipf }}$ браться ${ }^{\text {ipf }}$ за новую работу [...].

(В. Гроссман, Жизнь и судьба, ч. 1)

'He often had ${ }^{\text {ipf }}$ to take up ${ }^{\text {ipf }}$ some new job.'

In fact, with uacmo, the imperfective past tense is much more frequent than cases with a perfective past tense. To give an indication, a search in the NKRJa for [uacmo nриходилось] resulted in 196 hits (each with an imperfective infinitive), whereas the search for [иасто пришлось] resulted in only 4 examples (each with an imperfective infinitive). What, then, are the factors that trigger the perfective past tense in (43)? In explaining aspect here, it should be noted that in sentences with a perfective past tense and an imperfective infinitive [прийтись + infinitive $\left.{ }^{\mathrm{ipf}}\right]$, the construction usually has an ingressive meaning, and stresses that the necessity comes about:

(45) Его пришлось ${ }^{\mathrm{pf}}$ почти заново отстраивать ${ }^{\mathrm{ipf}}$ после бомбардировок союзников во время войны. (Туризм и образование, 2001.03.15)

'It [ = the city of Brest] had hf $^{\text {pf }}$ to be rebuild ${ }^{\text {ipf }}$ almost completely after the allied bombings during the war.'

Such sentences differ from sentences with a perfective infinitive $\left[\right.$ прийись + infinitive $\left.^{\mathrm{pf}}\right]$, where the focus is on the idea that the subject has given in to the necessity to realize the situation, cf. (46):

(46) Ей пришлось ${ }^{\mathrm{pf}}$ уехать $^{\mathrm{pf}}$ из города, где все на неё пальцем показывали.

(Автопилот, 2002.01.15)

'She had ${ }^{\mathrm{pf}}$ to go away ${ }^{\mathrm{pf}}$ from the town where all the people pointed their fingers at her.'

In sentences like (43) the perfective past tense auxiliary is triggered by the focus of attention on the fact that the necessity has occurred. Although this construction normally occurs with a perfective infinitive, this choice is overruled by the use of uacmo. A similar use occurs with other iterative expressions:

(47) Из-за плохого поведения ему за восемь лет пришлось ${ }^{\text {pf }}$ менять $^{\text {ipf }}$ школу 11 раз. (Вечерняя Москва, 2002.01.10)

'Because of his bad behavior he had ${ }^{\mathrm{pf}}$ to change ${ }^{\mathrm{ipf}}$ schools 11 times in 8 years.'

To recapitulate the main conclusion so far, we may say that the use of the perfective is possible with uacmo if the auxiliary expresses that the realization of the situation results 
in a particular state which is characterized by a period of repeated situations. It should be emphasized that this idea of a particular state is closely connected to the use of the past tense. In the case of the perfective present, which refers to future situations, this use is not possible (this means that there is no perfective present counterpart for sentences like (39) or (40)). ${ }^{9}$ The explanation for this lies in the fact that the realization of the situation expressed by the auxiliary introduces a whole period which is characterized by another repeated situation. This conceptualization of a lasting effect is difficult to combine with the future tense meaning of the perfective present, which focuses the attention on one specific moment in the future where the situation has yet to be realized.

I will now discuss the second context that allows for the perfective in the case of a past tense. As I already mentioned in Sect. 2, the perfective occurs with verbs with the ingressive prefix $3 a$-. In such sentences uacmo is used with verbs that express the beginning of a number of identical quick situations:

(48) Алена часто заморгала ${ }^{\mathrm{pf}}$ глазами.

(Е. Романова, Николай Романов. Дамы-козыри)

'Alena started blinking ${ }^{\text {pf }}$ her eyes quickly [lit. often].'

(49) Заныли мускулы, может быть, оттого, что чаще забилось ${ }^{\text {pf }}$ сердце [...]. (Лебедь (Бостон), 2003.11.30)

'My muscles started aching, perhaps, because my heart started beating ${ }^{\text {pf }}$ faster [lit. more often].'

The verbs from which these perfective examples are derived have a multiplicative or semimultiplicative meaning and express a series of momentary situations, which can easily be thought of as being realized in a quick succession. In (48) and (49) yacmo expresses that the intervals between the different occurrences are very small. This meaning is not expressed by много раз, which explains why one cannot substitute часто with много раз here.

A similar use occurs with delimitatives (with the prefix no-) if they are derived from (semi-)multiplicatives:

(50) В конце апреля в дверь дачи мелко и часто постучали ${ }^{\mathrm{pf}}$.

(С. Юрский, Жизнь)

'At the end of April someone softly and repeatedly [lit. often] knocked" ${ }^{\text {pf }}$ on the door of the dacha.'

(51) Послужил бы, как я, узнал бы, что почем,-тут он часто похлопал ${ }^{\mathrm{pf}}$ ладонью по лысине,-не говорил бы “з-завал”, сволочь.

(А. Найман, Славный конец бесславных поколений)

'If he had served like me, he would have found out what's what,- at this point he patted $^{\mathrm{pf}}$ his bald spot repeatedly [lit. often]—he wouldn't say 'o-obstruction', the bastard.'

${ }^{9}$ On the internet, very few counterexamples can be found:

[М]ечтал, что часто стану ${ }^{\mathrm{pf}}$ на озеро ездить ${ }^{\mathrm{inf}}$.

(http://magazines.russ.ru/novyi_mi/2002/2/varlamov.html; 05-27-2008)

'I dreamed that I would ${ }^{\mathrm{pf}}$ drive $^{\mathrm{ipf}}$ to the lake often.' 
Figure 3 Perfective past tense with nacmo and delimitative

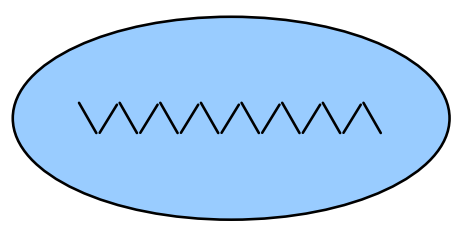

In Russian, delimitatives are usually formed from homogeneous intransitive verbs such as сидеть ('sit') or работать ('work') (see, e.g., Mehlig 2008, who discusses exceptions). By using the delimitative prefix the speaker focuses on a particular stretch of time in which the situation takes place, thereby conceptualizing the situation as a whole. Although in many cases the most natural interpretation is that the situation has taken place 'for a while', this is not a necessary interpretation (see for example Sémon 1986, 628-630; Petruxina 2000, 183-185; Melig 2006, 248-249; Dickey 2006). With uacmo, past tense delimitatives are not acceptable if they are derived from homogeneous intransitive verbs, cf. (52):

*Он часто погулял/посидел.

[intended reading: he often walked/sat a while]

This is because uacmo expresses an non-specific number of situations, and cannot be combined with a terminative (bounded) event such as sitting (a while / a particular period).$^{10}$ However, in (50) and (51) the delimitative is derived from a (semi-)multiplicative. Since muliplicatives express bundles of small events that occur in different series, the use of uacmo indicates that the intervals between the different subevents in one bundle are small. The reference to the quick succession of these events enables a conceptualization in which the different repeated situations are seen as a whole. In the Russian aspectual tradition such instances could be regarded as cases of the суммарное значение ('meaning of summarization') of the perfective (see, e.g., Bondarko 1971). The idea of summarization of repeated short momentary situations can be graphically represented as in Fig. 3 .

Sentences like (50)-(51) differ from similar sentences with an imperfective as in (7) because the focus is on the boundaries of the situation, and not on the situation in its progression. A typical context which requires this conceptualization is a narrative context like (9), where the situation is part of the narrative chain of events. In (51) the delimitative also seems to have an ingressive nuance, and expresses that the collection of short momentary situations has begun ('at this point he started to pat').

To summarize Sect. 3.1, uacmo strongly favors the imperfective, because it can be seen as an expression of open repetition. There are two major exceptions to this rule. First, the verb can be perfective if uacmo is not applied (directly) to it, but to another imperfective verb in the sentence. Second, the perfective is possible if uacmo is used in its secondary meaning of 'quick succession'.

\footnotetext{
${ }^{10}$ Sentences where nacmo refers to the auxiliary and the infinitive occurs with the delimitative are, however, not excluded:

Мы ж ее жалели, часто погулять ${ }^{\mathrm{pf}}$ пускали ${ }^{\mathrm{ipf}}$ допоздна.

(http://www.kp.ru/daily/23099.5/22834/; 05-27-2008)

'We felt sorry for her and often allowed ${ }^{\text {pf }}$ her to go out ${ }^{\text {ipf }}$ [lit. walk] until late.'
} 


\subsection{Aspectual behavior of много раз}

\subsubsection{Insights from the literature and the corpus}

As noted, the aspectual usage of иасто differs from много раз because много раз contains the word раз, and can be seen as an example of the class of closed repetition or iteration, like три раза ('three times'), несколько раз ('a number of times'), or $ә в а ж \partial ы$ ('twice'). Before I turn to the aspectual use with много раз, I will briefly discuss the aspectual use of closed repetition in general.

The aspectual use of closed repetition is analyzed in Sémon (1979), Mehlig (1982), and specifically Barentsen $(1992,1994,1997)$, who has devoted three very detailed analyses to the aspectual use of closed repetition on the basis of corpus data. From the results of these analyses one can conclude that in the case of closed repetition, both the perfective aspect and the imperfective aspect are possible in the past tense, each with a different meaning. In the case of the perfective aspect, the speaker conceptualizes the different occurrences of the situation as one whole. A possible context for this summarization is a bundle of occurrences' as a member of a chain of events, cf. (53):

\section{Я дважды повторил ${ }^{\mathrm{pf}}$ этот опыт и окончательно убедился.}

(В. Белов, Про ворон)

'I repeated ${ }^{\mathrm{pf}}$ the experiment twice, and finally convinced myself.'

The imperfective is chosen when the speaker focuses on each individual situation, for example because the effect of realizing the situation is cancelled:

(54) Я несколько раз начинала ${ }^{\text {ipf }}$ писать $^{\text {ipf }}$ и потом всегда бросала, и потом перечитывала, и потом было стыдно за написанное.

(В. Набоков, Соглядатай)

'I started ${ }^{\text {ipf }}$ writing $^{\text {ipf }}$ several times and every time I threw it away afterwards, and later on I reread it, and then I felt ashamed of what I had written.'

What about the aspectual use of много раз? The data given by Barentsen $(1992,1994)$ show that in cases of closed repetition where the number of occurrences is very high, such as сто раз ('a hundred times') оr много раз ('many times'), the imperfective is usually chosen. The explanation for this is that the more often a situation is repeated, the more difficult it is to summarize these situations into one whole. Много раз therefore easily suggests the idea of a constant flow of situations as in Fig. 1, where the boundaries cannot be established. In contrast to uacmo, however, the perfective is not excluded (Sémon 1979; Barentsen 1992, 1994). ${ }^{11}$ The occurrence of such perfective cases clearly indicates that много раз аnd иасто cannot be seen as synonymous. As I will show, the reason why perfective cases are possible is exactly because много раз expresses the idea of 'time' or 'occurrence'.

\footnotetext{
${ }^{11}$ In Barentsen's sample of 34 sentences with много раз, there were 4 examples with a perfective (Barentsen 1994, 3, 42). Two of them contained a past tense. Of these two, one example occurred with иуть не ('barely'), which has a very strong correlation with the perfective, and one example occurred with прийтись and an imperfective infinitive, which, as we have shown before in the discussion of uacmo, can trigger a perfective in particular contexts. In my sample of 102 sentences with много раз, only 5 examples were attested with a perfective aspect (see Appendix B). One contained a past tense and a perfective infinitive, one a past tense modal predicative (надо было 'it was necessary') with a perfective infinitive, one occurred with a past tense (with иуть не) without an infinitive, and two with a perfective future tense (both with еще раз, еще, еще много раз 'one more time, and still many times').
} 
In my sample of 102 sentences with много раз, only about $5 \%$ contained a perfective verb (see Appendix B). In order to gain more insight into the factors that trigger the perfective with много раз, I have looked at the use of the perfective past tense in the whole NKRJa. I have focused on the use of the perfective past tense, precisely because this use is almost excluded with uacmo. The search in the NKRJa resulted in several examples of perfective past tense. Some sentences contained a past tense of прийтись or other similar modal verbs and an imperfective infinitive, as in (55), or perfective verbs that express the concept of succeeding, and a perfective infinitive (such as ycnemb 'succeed' or довестись 'manage'), as in (56):

(55) И действительно, много раз еще пришлось ${ }^{\text {pf }}$ Андрею удивляться ${ }^{\text {ipf }}$ тому, что сделали москвички в прифронтовой полосе. (М. Бубеннов, Белая береза) 'And really, still many times Andrej had ${ }^{\mathrm{pf}}$ to wonder $^{\mathrm{ipf}} /$ couldn't help ${ }^{\mathrm{pf}}$ wondering $^{\text {ipf }}$ about what the Muscovite women did at the front.'

(56) Пока мы куковали на своем необитаемом острове, бури, к счастью, ни разу не было, но вепря нам много раз довелось ${ }^{\mathrm{pf}}$ услышать $^{\mathrm{pf}}$ и несколько раз увидеть. (Н. Воронель, Без прикрас. Воспоминания)

'While we were cuckooing on our uninhabited island, there fortunately wasn't a single storm, but many times we managed ${ }^{\mathrm{pf}}$ to hear $^{\mathrm{pf}}$ and a few times to see a wild boar.'

Below, I will focus on the use of the perfective past tense in sentences without an infinitive. The search in the NKRJa for a perfective past tense without an infinitive resulted in 41 instances (from both the nineteenth and twentieth century). The data suggest that some verbs more easily occur in the perfective past tense with много раз than other verbs, and that it is not a coincidence that the examples provided in Sémon (1979) contain the verbs поиеловать ('kiss'), пройти ('pass, reach') and показать ('show'). In Table 4 an overview is given of the perfective past tense verbs that occur without the infinitive, and the number of imperfective counterparts. ${ }^{12}$

The data suggest that the reason why a perfective is used is closely connected to the meaning of the verb. Note, for example, that no perfective counterparts were found for most of the verbs that occur relatively frequently with много раз (see Appendix B): пьттаться, приходить, делать, говорить аnd видеть. Furthermore, many of the verbs that are typical of the perfective with много раз are also typical of contexts of closed repetition in general, including contexts with adverbs of low iteration like дважды. Examples are пройти, поцеловать, and перечитать which occur in Table 4, but which are also among the most frequently attested perfective verbs with closed repetition in general (see Barentsen 1997). This suggests that the exceptions to the strong correlation between много раз and the imperfective are based on the same principles that play a part in the choice of aspect with closed repetition in general. Below, I will discuss these factors in more detail, with respect to narrative and retrospective contexts.

\subsubsection{Narrative contexts}

In the NKRJa a few instances were found of a perfective past tense and много раз used in a narrative context. In such sentences the perfective is used with verbs that express a

\footnotetext{
${ }^{12}$ The search was conducted as follows: много раз [distance 4] pf/ipf and pf/ipf [distance 4] много раз.
} 
Table 4 Verbs and their aspect with много раз in NKRJa

\begin{tabular}{|c|c|c|}
\hline & Perfective & Imperfective \\
\hline вернуться/возвращаться 'return' & 1 & 4 \\
\hline вылерпеть/терпеть 'bear' & 1 & 0 \\
\hline дать/давать 'give' & 1 & 7 \\
\hline доказать/доказывать 'prove' & 3 & 2 \\
\hline зевнуть/зевать 'уаwn' & 1 & 0 \\
\hline назвать/называть 'call' & 1 & 3 \\
\hline написать/nисать 'write' & 1 & 13 (1 with -cя) \\
\hline обмануть/обманывать 'deceive' & 1 & 4 (2 with $-c я)$ \\
\hline объездить/- 'drive round' & 1 & - \\
\hline опередить/опережать 'overtake' & 1 & 0 \\
\hline отозваться/отзываться 'respond' & 1 & 0 \\
\hline отмерить/отмерять 'measure' & 1 & 0 \\
\hline передумать/передумывать 'think over' & 1 & 0 \\
\hline перечитать/перечитывать 'reread' & 4 & 13 \\
\hline побывать/бывать 'be' & 2 & 44 \\
\hline повернуть/повертывать, поворачивать 'turn' & 1 & 0 \\
\hline повторить/повторять 'repeat' & 2 & 43 (18 with -cr) \\
\hline показать/показывать 'show' & 1 & 6 \\
\hline посетить/посещать 'visit' & 1 & 1 \\
\hline посмотреть/смотреть 'look' & 1 & 8 \\
\hline поцеловать/иеловать 'kiss' & 3 & 2 \\
\hline помочь/помогать 'help' & 1 & 3 \\
\hline прогудеть/гудеть 'hoot', 'buzz' & 1 & 0 \\
\hline пройти/проходить 'go through' & 5 (one пройтись) & 5 \\
\hline прочитать/прочитывать 'read through' & 1 & 0 \\
\hline сменить/сменять 'change' & 2 & 1 (with $-c я$ ) \\
\hline уехать/уезжать 'leave' & 1 & 1 \\
\hline
\end{tabular}

situation which can easily be thought of as occurring in a bundle of situations. The different situations are taken together as one single whole which occurs as a part in the narrative chain of events. Note that in contrast to часто, много раз allows for this conceptualization because it refers to specific occurrences of an event. This is for example the case with поцеловать since this verb expresses a situation which usually occurs in series, but as (58) and (59) show, other verbs occur as well:

(57) Лариса кинулась на шею Александре Ивановне и много раз кряду ее поцеловала $^{\text {pf }}[\ldots]$. (Н. Лесков, На ножах)

'Larisa threw herself at Aleksandra Ivanovna's neck and kissed ${ }^{\text {pf }}$ her many times in a row.'

(58) [O]кончив деловой разговор, она призвала своего двухлетнего сына, много раз его повернула ${ }^{\mathrm{pf}}$ передо мною и начала его снаряжать на прогулку.

(Н. Лесков, Дама и фефёла) 
'Having finished her business conversation, she called her two year old son, turned $^{\mathrm{pf}}$ him around many times in front of me and started to make him ready for a walk.'

(59) Много-много раз повторила ${ }^{\mathrm{pf}}$ она один мотив. Потом запела другой романс [...]. (П. Боборыкин, Василий Теркин)

'Many, many times she repeated $^{\mathrm{pf}}$ the same melody. After that she started to sing another romance.'

Such sentences can be compared to similar sentences with an imperfective such as the following, where the use of пока ('until'), suggests an ongoing situation of kissing Marfen'ka, which partly runs parallel to her falling asleep:

(60) Долго шептали они, много раз бабушка крестила и целовала ${ }^{\text {ipf }}$ Марфеньку, пока, наконец, та заснула на ее плече. (И. Гончаров, Обрыв)

'They whispered for a long time, many times grandmother crossed herself and kissed $^{\text {ipf }}$ Marfen'ka, until, eventually, she fell asleep on her shoulder.'

Sentences with много раз and a perfective aspect in a narrative context are rather infrequent. This can be attributed to the fact that много раз typically presupposes a larger time span, and is not easily associated with a chain in the narrative discourse with most verbs. As such, it differs from expressions that express a smaller number of occurrences like несколько раз оr дважды as in (53). This explains why the verb попытаться/пытаться, which frequently occurs with много раз, always occurs with an imperfective aspect in the NKRJa, whereas with несколько раз the use of the perfective is fully acceptable:

(61) Митрофан Афанасьевич несколько раз попытался ${ }^{\mathrm{pf}}$ заговорить со своей мамой [...]. (Ю. Петкевич, Возвращение на родину)

'A couple of times Mitrofan Afanas'evič tried ${ }^{\mathrm{pf}}$ to talk to his mother.'

Попытаться is typically used in a narrative context. In such contexts the use of много раз is not acceptable in most contexts because it normally presupposes a larger time span.

\subsubsection{The use of the perfective with много раз in retrospective contexts}

The majority of sentences with много раз and a perfective past tense have a so-called retrospective (perfectum) character. In such sentences the effect or result of a collection of occurrences of a situation is evaluated at a particular vantage point. Again, много раз allows for this conceptualization of summarization because the meaning of 'time' or 'occurrence' makes it possible to view the collection of repeated events as a whole with specific boundaries. Whether or not such a summarization is possible largely depends on the meaning of the verb. This can be illustrated with the verb nрuходumb, which is among the most frequently attested verbs in our sample of много раз (see Appendix B). This verb always occurs in the imperfective aspect when combined with много раз:

(62) Много раз приходил ${ }^{\mathrm{ipf}}$ он к нам в редакцию газеты.

(Наш современник, 2002)

'Many times he visited ${ }^{\text {ipf }}$ us at the newspaper's editorial office.'

The explanation is that in a restrospective context, приходить is typically interpreted as a case of аннулированность результата ('cancelling of the result'). A sentence like the following is therefore normally interpreted to mean that the person who has come has left again: 


\section{(63) Ко мне приходил ${ }^{\mathrm{ipf}}$ врач.}

'The doctor came ${ }^{\mathrm{ipf}}$ to see me.'

This is because there are different verbs for the different movements of coming and going, which form an antonymous pair (прийти - уйти). Because of this it is not possible to summarize the different instantiations of the situation into one situation: coming many times presupposes going (leaving) many times. This differs from the verb пройти, which occurs relatively frequently with много раз and a perfective past tense. This is because this verb expresses the idea of a particular path with a beginning and an end, which can be repeated several times by proceeding along the same path, and by each time returning to the starting point. Some verbs strongly favor the imperfective, but allow for the perfective in specific contexts. This is for example the case with yŭmu/yxoдumь ('leave'), which expresses the movement away from something. This verb typically occurs with an imperfective in the case of много раз:

(64) Уже закончилась программа, уже много раз я уходила ${ }^{\text {ipf }}$ за кулисы и опять выходила на сцену. (Л. Гурченко, Аплодисменты)

'The show had already ended, and I had already gone ${ }^{\text {inf }}$ behind the curtains and returned to the stage many times.'

Again, in such sentences it is difficult to summarize the different occurrences of leaving into one situation because yŭти/уходить focuses the attention on the movement away from something, and is not easily associated with the idea of returning to the same place as part of the same movement. In the corpus there were 18 examples with yxoдumb and no example with yŭmu. There was, however, one example with yexamb ('leave by means of a vehicle'):

(65) Мы уже и уехали ${ }^{\mathrm{pf}}$, и вернулись ${ }^{\mathrm{pf}}$ внутри себя много раз.

(Домовой, 2002.03.04)

'We had already left ${ }^{\mathrm{pf}}$ and returned ${ }^{\mathrm{pf}}$ to our inner selves many times.'

Here the use of the perfective is possible because the leaving and returning are seen as one whole, which is emphasized by the use of yже $и \ldots . . u$ ('already both $\mathrm{X}$ and $\mathrm{Y}$ ') (cf. example (48) in Barentsen 1997, 21).

What then are the factors that trigger a perfective, and how are they related to the lexical meaning of the verb? Below, I will discuss the following contexts in which a perfective is used:

(i) The result is strongly present at a particular vantage point.

(ii) The perfective, but not the imperfective, is associated with a result (conative use of the imperfective).

(iii) The perfective focuses on the result rather than on the realization of the situation in the past.

(iv) The perfective focuses on the quantity of the repetition, whereas the imperfective focuses on the occurrence of the situation as such.

(v) The perfective, but not the imperfective, expresses a short momentary situation (semelfactive perfective).

First, in some sentences the choice of the perfective is motivated by the focus on the idea of a result, which is strongly present at the moment of speech or another vantage point. This is for example the case in (66) with the perfective verb нanucamb ('write'): 
(66) На серой колонне какой-то осёл много раз подряд химическим карандашом написал $^{\mathrm{pf}}$ свою фамилию и украсил её огромным росчерком и закорючкой. (Ю. Домбровский, Обезьяна приходит за своим черепом, часть 2)

'On a grey column some fool wrote ${ }^{\text {pf }}$ his surname many times in a row with an indelible pencil, and decorated it with enormous strokes and hooks.'

Here, by using the perfective, the speaker focuses his attention on the effect of the writing which is still present at the moment of speech: the same name is written down several times on the column. In contrast, in the case of the imperfective the focus is on each realization of the situation as such or on the realization of a situation in different occurrences, cf. (67):

(67) Естественно, я ничего нового не открываю, об этом уже много раз писали ${ }^{\text {ipf }}$ и говорили. (А. Журбин, Как это делалось в Америке. Автобиографические заметки)

'Naturally, I'm not discovering anything new, people have written ${ }^{\text {ipf }}$ about it and discussed it many times already.'

Second, Barentsen $(1994,7)$ suggests that the perfective is also typical of verbs where the imperfective can be associated with the attempt, rather then the result, which is also called conative use of the imperfective past tense. His observations are sustained by the data from the NKRJa, since one of the perfective past tense verbs that is attested more than once is доказать ('prove'), a verb which also figured in Sémon's analysis (1979). An example from the NKRJa is given below:

(68) И странное дело, Вильгельм был бретер, смерть его не страшила, он слыл бешеным и много раз доказал ${ }^{\mathrm{pf}}$ это [...]. (Ю. Тынянов, Кюхля)

'And what's strange, Wilhelm was an eager fighter, death didn't frighten him, he was considered to be fanatic and many times proved ${ }^{\mathrm{pf}}$ this right.'

In this sentence the speaker uses the perfective to stress the result of the realization of the situation, rather than the attempt, as is the case in the following example from the Internet:

(69) Я много раз доказывал ${ }^{\mathrm{ipf}}$, что люблю её, Пейдж. Неужели это тебя не убедило? (club.ctc-tv.ru/viewtopic.php?t=11600)

'I have proven ${ }^{\text {ipf }}$ many times that I love her, Page. Didn't that convince you?'

Note, however, that in contrast to the suggestion in Barentsen $(1994,8)$, the data found in the NKRJa do not sustain the hypothesis that the imperfective necessarily points to an attempt only. In the following sentence, the imperfective is used, whereas the context strongly suggests that the attempt to prove something was successful on various occasions:

(70) Однако ничто не может быть яснее этого, и императрица много раз это доказывала ${ }^{\mathrm{ipf}}$. (Е. Тарле, Чесменский бой и первая русская экспедиция в Архипелаг (1769-1774))

'However, nothing can be clearer than that, and the empress has proven ${ }^{\text {inf }}$ this many times.'

The difference in meaning between sentences with a perfective like (68) and sentences with an imperfective like (70) is primarily a difference in focus. Whereas the perfective stresses the idea of a result, sentences with an imperfective stress the idea that the situation has occurred as such, and may be associated with the idea of an attempt only. 
The association between the perfective and the idea of a result also explains why some verbs cannot be used with the perfective aspect. Take for example the imperfective verb видеть, which occurs relatively frequently with много раз in my sample of sentences (see Appendix B):

(71) Конечно, я много раз видел ${ }^{\mathrm{pf}}$ В. И. Качалова в этой роли.

(В. Давыдов, Театр моей мечты)

'Of course, I saw ${ }^{\text {ipf }}$ V. I. Kačalov in that role many times.'

However, in the NKRJa no examples were attested with много раз and увидеть- the perfective counterpart of видеть. As is remarked by Barentsen, (1997, 24, 25) verbs of perception do not allow for the perfective in the case of closed repetition nor in a retrospective context. He explains this by the lexical semantics of these verbs, more specifically by the fact that the imperfective verb already expresses features which are associated with the idea of a result (cf. Maslov 1948, who speaks of a class of verbs with the feature of непосредственный, непрерывный эффект 'immediate, constant effect'). A similar explanation may be given for sentences with много раз.

Third, with some verbs both the perfective and imperfective are associated with the effect of the realization of the situation, but the way in which the realization of the situation is conceptualized differs. Consider for example the perfective verbs nереиитать ('reread') and прочumamь ('read through'):

(72) Я много раз перечитал ${ }^{\mathrm{pf}}$ это письмо. Я написал также сам несколько писем, но у меня не было никаких адресов [...]. (А. Грин, Золотая цепь)

'I reread ${ }^{\mathrm{pf}}$ that letter many times. I also wrote some letters myself, but I didn't have any addresses.'

(73) Всю классику от древнегреческих трагедий до романов Абэ Кобо прочитала ${ }^{\text {ff }}$ много раз. (Д. Донцова, Доллары царя Гороха)

'I have read ${ }^{\mathrm{pf}}$ all the classics from ancient Greek tragedies up to Abe Kobo's novels many times.'

These verbs allow for a summary conceptualization, even if the repetition takes place on different occasions, because the meaning of nepe- ('re-') or npo- ('through') presupposes with regard to the same object that the action is started over again from the beginning. In sentences with a perfective aspect the focus is primarily on the situation at a particular vantage point (typically the moment of speech), where the effect of repeating the action many times is evaluated. In the corpus, we also find sentences with the secondary imperfective of переиитать:

(74) Мне что-то сегодня очень грустно [...]. Виера много раз перечитывала ${ }^{\text {ipf }}$ ваши письма. Почему же мне грустно, Боря? (Б. Левин, Голубые конверты) 'For some reason I feel very sad today. Yesterday I reread ${ }^{\text {ipf }}$ your letters many times. Why then, do I feel sad, Borja?'

(75) Много раз в жизни перечитывал ${ }^{\mathrm{ipf}}$ я потом "Первую любовь" [...].

(Шахматное обозрение, 2004)

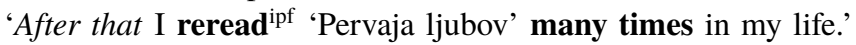

The main difference between the perfective and the imperfective is that by using the imperfective the focus of attention is more on the realization of the situation in the past. 
For example, in (75) the use of потом ('after that') focuses the attention on a particular part of the life of the speaker, which creates the idea that this period is for some reason characterized by the presence of an iterated situation. Similarly, in (74) the use of виера ('yesterday') focuses the attention on a specific moment in the recent past, where the subject performs the situations many times. In some cases, the focus on the past even more clearly implies the idea of the situation in its progression. This is evident in the following example from the Internet, where the imperfective прочитывать is used in a narrative context:

(76) В своем ответе фарисеям Христос подробно осветил этот вопрос, но когда я много раз прочитывал ${ }^{\text {ipf }}$ этот отрывок, то почему-то мое внимание привлекло одно предложение из ответа Христа.

(www.hopeofsalvation.org/cf/?part=article\&issue=23\&id=1)

'In his answer to the Pharisees, Christ shed light on that question, but while I was rereading $^{\text {ipf }}$ that part many times [over and over again], one of the sentences from Christ's answer for some reason caught my attention.'

Example (76) provides a clear context for the imperfective, because the repeated situation in the subordinate clause forms the background for the situation in the main clause.

Fourth, with some verbs the perfective focuses on the quantity of the repetition, whereas this focus is absent in sentences with an imperfective. This is for example the case with verb of motion пройти, which is attested relatively frequently in the NKRJa (see Table 3), and also figures in Sémon's (1979) analysis:

(77) Они прошлин ${ }^{\mathrm{pf}}$ много раз до аптеки и назад. (Sémon 1979, 98)

'Many times they had walked ${ }^{\mathrm{pf}}$ up to the pharmacy and back.'

(78) Мижуев прошел до конца набережной и вспомнил, что уже много раз прошел $^{\mathrm{pf}}$ ее из конца в конец. (М. Арцыбашев, Миллионы)

'Mižuev reached the end of the embankment and remembered that he had already gone $^{\text {pf }}$ many times from there to the other end.'

As Barentsen (1997, 20) remarks, пройти can easily occur with expressions of closed repetition, because it expresses a movement back and forth the same path, without changing the character of the movement. Sentences like (77) and (78) can be contrasted with sentences containing an imperfective verb:

(79) Татарский много раз проходил ${ }^{\mathrm{ipf}}$ мимо этого здания; давным-давно кто-то говорил ему, что это секретный институт, где разрабатывают новые виды оружия. (В. Пелевин, Generation "П”)

'Tatarskij walked ${ }^{\text {ipf }}$ past that building many times; a very long time ago someone had told him that this was a secret institute, where new kinds of weapons were developed.'

(80) Но путь был известный, хотя и странный: словно не был здесь никогда, но много раз во сне проходил ${ }^{\text {ipf }}$ этой дорогою.

(Б. Екимов, Возле стылой воды) 
'But the road was familiar, although strange as well: in reality I had never been here, but in my dream I had travelled ${ }^{\text {ipf }}$ along that road many times.'

Sentences with an imperfective aspect seem to be close to so-called instances of the общефактическое значение ('general-factual use') of the imperfective. This means that the imperfective is used in the case of a completed terminative situation to focus on the fact that the situation has occurred as such. Such sentences differ from sentences with a perfective, where the idea of quantification is emphasized, and the focus is on the fact that the situation has occurred many times. In (77) and (78) this feature is probably connected to the larger context, where it is stressed that the whole path has already been crossed many times: 'all the way to $\mathrm{X}$ and back again'. Such a conceptualization is absent in (79) with an imperfective past tense, where the speaker expresses that the subject has passed a particular building on several different occasions.

Finally, the reason for the occurrence of the perfective may also be that an imperfective does not exist or has a slightly different lexical meaning. This is clearly the case with semelfactive verbs, as in (81):

(81) И по реке кто-то сонно и замирая много раз зевнул ${ }^{\mathrm{pf}}$.

(А. Серафимович, У обрыва)

'And on the river, someone yawned ${ }^{\mathrm{pf}}$ [give a yawn] several times, sleepily, while the sound faded away.'

In (81) the use of the perfective can be motivated by the semelfactive meaning of the verb. By using the corresponding multiplicative imperfective зевать ('yawn') the idea of multiple occurrences of short momentary or punctiliar actions would not be stressed. Note that the use of the semelfactive is also typical of expressions of closed repetition which express a low iteration (see Barentsen 1997, 15-17). In the case of много раз, however, only one example with a semelfactive verb was attested in the corpus (81). The explanation for this is that много раз is frequently used in contexts where the situations occur within a relatively large time span, and where the idea of a short momentary or punctiliar action is not relevant. This explains why in the following sentence, the multiplicative кричать ('shout') is used instead of the semelfactive perfective counterpart крикнуть ('(give a) shout'):

(82) По-моему, я его много раз кричал ${ }^{\text {ipf }}$ вам. (В. Дудинцев, Белые одежды)

'In my opinion, I have shouted ${ }^{\text {ipf }}$ that at you many times [on various occasions].'

\subsubsection{The use of delimitatives and много раз}

Since I have discussed the use of delimitatives with nacmo in Sect. 3.1, I will briefly discuss the use of delimitatives with много раз. It should be noted that in contrast to иасто, много раз does not occur with delimitatives that are derived from multiplicatives:

(83) ? Он много раз постучал ${ }^{\mathrm{pf}}$.

[intended meaning: he knocked many times]

This is because иасто, but not много раз, can refer to a quick succession of short events, which makes it possible to summarize the different events into one whole. In contrast to 
nacmo, however, the use of delimitatives derived from homogenous intransitive verbs is possible. In the NKRJa I could not find any examples with past tense delimitatives, but on the Internet, examples of past tense delimitatives derived from atelic verbs like сидеть ('sit'), and бродumь ('wander') can be found: ${ }^{13}$

(84) Но все же я неплохо провел время, поел ${ }^{\mathrm{pf}}$ свежей дичи и рыбы, много раз посидел ${ }^{\mathrm{pf}}$ за “охотничьим" столом, пожил $\AA^{\mathrm{pf}}$ в палатке и т.д.

(www.aleksandrov.ru/news.php?id=2321\&PHPSESSID=1f80206b244c33fa528453; 05-27-2008)

'But still I didn't have a bad time, I ate [for a while] some fresh wild game and fish, many times I sat ${ }^{\mathrm{pf}}$ [for a while] at the 'hunter's table', I lived [for a while] in a tent etc.'

(85) И только после того, как я много раз побродил ${ }^{\mathrm{pf}}$ по этим удивительным улочкам, сложилось впечатление, что ничего подобного на североафриканской земле нет.

(http://www.sweeta.ru/voyage.html; 05-27-2008).

'And only after I had wandered" ${ }^{\mathrm{pf}}$ many times through those remarkable little streets, the impression took shape that there was nothing like that on North-African soil.'

By using the delimitative prefix the speaker focuses on a particular stretch of time in which the situation occurs, as such conceptualizing the situation as a whole. By combining it with много раз, the speaker makes explicit that there are several such (temporally bounded) events. Even though the repetition of an aterminative verb such as бродить in itself implies different bounded events, the boundaries of the situations are not focused on in similar sentences without a delimitative prefix:

(86) В жаркие летние дни я много раз бродил ${ }^{\text {ipf }}$ по его отвалам, безуспешно пытаясь найти путь в глубоко лежавшие под поверхностью степи выработки.

(И. Ефремов, Путями старых горняков)

'On hot summer days I wandered ${ }^{\text {ipf }}$ many times over its sand hills, trying in vain to find entry to the mineshafts lying deep under the surface of the steppe.'

The reason for using a delimitative prefix may be twofold. First, the speaker may want to stress that the situation took place for only a short while. This is the case in (84), where the delimitative is used in a context of other delimitatives, which each express short situations (nоесть 'eat for a while', пожить 'live for a while'). Second, it may be that the focus on

\footnotetext{
${ }^{13}$ In the NKRJa I attested one example with прийтись and the perfective infinitive nоуиаствовать, which is derived from the imperfective уиаствовать ('participate'):
}

Эдику пришлось ${ }^{\mathrm{pf}}$ много раз поучаствовать ${ }^{\mathrm{pf}}$ в солдатской службе, когда у отца в роте появился сержант Махитарьян.

(Э. Лимонов, У нас была Великая Эпоха)

'Edik had ${ }^{\mathrm{pf}}$ to participate $^{\mathrm{pf}}$ many times in the military service, when sergeant Maxitar'jan appeared in his father's company.'

In this case, the perfective is probably used because the speaker wants to emphasize that the subject has given in to the necessity (cf. the analysis given in Sect. 3.1). Because уиаствовать has no unprefixed perfective counterpart, the optimal way to perfectivize it is by using the prefix no-. In this case the typical delimitative meaning of 'a while' is not present, and the prefix no-seems to function as the regular perfective counterpart of уиаствовать. As such, I agree with Dickey (2006), who stresses that no- is often used as the default perfectivizing prefix in the case of verbs that otherwise do not have a perfective counterpart. 
the boundaries is also connected to factors which trigger the perfective in other contexts as well. This is the case in (85), where the delimitative may partly be due to the use of nocлe того, как ('after that'), which focuses the attention on the moment when the situation is realized.

To summarize Sect. 3.2, много раз favors the imperfective aspect, because it expresses a very large number of repeated situations. In contrast to uacmo, however, the perfective aspect is not excluded. The perfective aspect is possible if the repeated situations are construed as a whole, which may be the case in the narrative chain of events. The perfective is also possible in the case of retrospective contexts, where the focus is on the result or effect of the realization of the repeated situations.

\subsection{Aspectual behavior of много}

The expression много differs from both иасто and много раз because it does not inherently have a temporal dimension, and the idea of repetition or frequency must be seen as an interpretation, rather than as part of the meaning of this form. In Barentsen (1992, 1994, 1997) and Sémon (1979) sentences with много (without раз) are not discussed, probably because they cannot strictly be seen as instances of the class of iterative or frequency adverbs. Bitextina $(1975,67)$, however, points out that while there are exceptions, the general rule is that sentences with много are imperfective. She also remarks that if the verb is transitive, the use of the perfective aspect is not possible in the majority of cases, and много functions as the object of the verb. The analysis is confirmed by the data in my survey of 100 sentences (see Appendix C), where only one perfective example was attested.

In my view, the explanation for why the imperfective is typical of sentences with много (and a past tense) is that in these sentences the focus is on the quantity of the situation. This may be because a single situation is associated with a long duration or quantity, or because a non-specified number of occurrences of a situation is taken together and evaluated as being a lot. In both contexts the situation or collection of situations is easily associated with the idea of homogeneity, for which the imperfective aspect is obligatory (with the exception of delimitative verbs).

With respect to the exceptions to the rule that the aspect is imperfective, много displays similarities both to часто and много раз, but also has some features which are not typical of the other two expressions. As regards the similarities to иасто and много раз, the perfective is possible in the past tense with the modal verb прийтись and an imperfective infinitive:

(87) Очень жаль, что тебе так много пришлось ${ }^{\text {pf }}$ страдать $^{\text {ipf }}$.

(А. Кони, Пропавшая серьга)

'It's such a pity that you had ${ }^{\mathrm{pf}}$ to suffer ${ }^{\text {ipf }}$ so much.'

Similarly, as in the case of uacmo, the perfective is used with the inchoative verb cmamb ('start'), which occurs with an imperfective infinitive:

(88) Когда ей было 35 лет, сгорел дом больной, после этого стала ${ }^{\text {pf }}$ много плакать $^{\text {ipf }}$, нервничать $^{\text {ipf }}$, резко проявлялась нерешительность.

(Т. Гейер, К вопросу о пресенильных психозах)

'When she was 35 years old, the sick woman's house burned down. After that she started $^{\text {pf }}$ to cry ${ }^{\text {ipf }}$, worry ${ }^{\text {ipf }}$ a lot and became very indecisive.' 
In the NKRJa examples are found with the verbs пройти and перечитать:

(89) Был в Загорске. [...] Много прошел ${ }^{\mathrm{pf}}$ пешком.

(В. Крупин, Выбранные места из дневников 70-х годов // Наш современник, 2004)

'I was in Zagorsk. I walked ${ }^{\mathrm{pf}}$ a lot.'

(90) Много перечитали ${ }^{\mathrm{pf}}$, благо наш клуб находится в библиотеке N 5 г. Кирова, занялись поисковой работой.

'We read" ${ }^{\text {pf }}$ a lot, since our club is in library number 5 of the city of Kirov, and did searches.'

Although in these sentences the idea of repetition is not very prominent, I do not think it is a coincidence that the two lexical verbs attested here are also typical of the perfective use of много раз (see Sect. 3.2.3).

Now, let us proceed to the aspectual properties which are specific to много. Bitextina $(1975,67)$ mentions that the perfective can be found in the case of verbs with the prefix $\mathrm{Ha}$-, which indicates that the verb is associated with a large quantity, and the delimitative prefix no-, which presents an unbounded situation as bounded:

(91) Я много наслыша[л] ${ }^{\mathrm{pf}}$ об этом чудесном крае. ${ }^{14}$

'I have heard ${ }^{\mathrm{pf}}$ a lot about that wonderful region.'

(92) Он много потрудился ${ }^{\mathrm{pf}}$ в своей жизни.

'He worked ${ }^{\mathrm{pf}}$ a lot in his life.'

Bitextina's remarks are confirmed by data from the NKRJa, where similar examples were attested:

(93) Много нагрешил ${ }^{\mathrm{pf}}$ ты, заплатил недешево.

(Б. Зайцев, Улица св. Николая)

'You have sinned ${ }^{\mathrm{pf}}$ a lot, and paid a dear price.' 15

(94) Направляюсь на Запорожье в села, где я со своими товарищами слишком много поработал ${ }^{\mathrm{pf}}[\ldots]$. (Н. Махно, Воспоминания)

'I am going to Zaporož'e to villages, where I did ${ }^{\text {pf }}$ too much work with my comrades.'

Examples like (91) or (93) are similar to cases where the adverb functions as the object:

(95) Книг много накупил ${ }^{\mathrm{pf}}$ и дома расставил, чтобы хорошим девушкам нравиться. (zhurnal.lib.ru/b/bakirowa_n_w/zh-b.shtml; 05-27-2008)

${ }^{14}$ In (91) it is also possible to interpret много as the object of the verb ('I have heard a lot of beautiful things').

${ }^{15}$ In my sample from the NKRJa one example was found with the verb напетлять ('to loop', 'to meander'):

В осиннике я снова наткнулся на его старый след. Много он напетлял ${ }^{\mathrm{pf}}$ по лесу. (Ю. Коваль, Сиротская зима)

'In the aspen bush I came across his old traces again. He had meandered ${ }^{\mathrm{pf}}$ a lot through the forest.'

In this sentence we find the prefix на-, but it does not have a clear quantitative meaning. Perhaps the perfective aspect is triggered here because the speaker wants to emphasize the result of the action at the speech moment, that is, he points to the proof that the hare has wandered around the woods. It may be possible to speak of an accumulation of different movements, which results in a large amount of prints in the forest. As such, this case could be seen as semi-quantitative. 
'He bought ${ }^{\mathrm{pf}}$ a lot of books and placed them all over his house, in order to please nice girls.'

This shows that there is a close association between the idea of много as an actual syntactic object of the verb, and много as a modification of the verb. Even in the latter case, the verb itself is easily associated with a large quantity (here, a lot of things heard, or a lot of sins).

The reason why много can easily occur with a delimitative prefix, is also due to its meaning of quantification. ${ }^{16}$ In order to illustrate this, I will first have a closer look at the type of delimitatives that occur with много. In the NKRJa and on the internet examples can be found with two types of verbs: (i) verbs that express a movement such as nобродить ('wander'), or a physical position such nocuдemb ('sit'), and (ii) verbs that express the idea of working (поработать, потрудиться). First, let us consider verbs that express a movement or stative position:

(96) Я много постоял ${ }^{\mathrm{pf}}$ и посидел ${ }^{\mathrm{pf}}$ на парапете, глядя на город ночью сверху, рассуждая и рисуя. (forum.comtel-vologda.ru/viewtopic. php? $=432549 \&$ highlight $=\& \operatorname{sid}=156 f 45280$ ef74da774031a91336acbd3; 02-01-2008)

'I stood ${ }^{\mathrm{pf}}$ and sat ${ }^{\mathrm{pf}}$ a lot on the parapet, looking at the city at night from above, thinking and drawing.'

(97) Знать, много по свету побродил ${ }^{\mathrm{pf}}$, всякого разного успел наслушатьсянасмотреться. (М. Семенова, Волкодав: Знамение пути)

'Evidently, I have wandered ${ }^{\mathrm{pf}}$ around the world a lot, and have succeeded in seeing and hearing many things.'

(98) День был отличный. Завтракал Фредерикс. Много погуляли ${ }^{\mathrm{pf}}$ в Баболовском парке. (www.orthomed.ru/ftproot/abort_mr/books/history/library/diaris/1915.htm; 05-27-2008)

'It was a beautiful day. Frederiks came to have breakfast with us. We walked $^{\text {pf }}$ a lot in the Babolovskij park.'

In sentences like these the adverb много quantifies over a bounded event, or a bundle of events, which is conceptualized as bounded. The idea of 'a while' is not necessarily present. As is remarked by Sémon (1986, 628), and Mehlig (Melig 2006, 249), the use of a delimitative can in fact be triggered by references of a large duration or large quantity. Both authors provide examples with много:

(99) Ему довелось много поездить ${ }^{\text {pf }}$. (Melig 2006, 249)

'He managed to travel ${ }^{\mathrm{pf}}$ a lot.'

(100) Нужно много попотеть ${ }^{\mathrm{pf}}$, прежде чем с ними справяться.

(Sémon 1986, 628)

'You have to sweat ${ }^{\mathrm{pf}}$ a lot, before you can deal with them.'

The data from the NKRJa confirm this hypothesis, since a verb like nonomemb frequently occurs with an adverb like изрядно ('rather much'), often in combination with a modal predicate, as in example (100). According to Mehlig (Melig 2006, 249), this use of delimitatives is typical of repeated situations, but as is shown by (98) sentences with много

\footnotetext{
${ }^{16}$ The perfective aspect is also used in sentences where the function of the quantifier is close to that of an intensifier as in (32). This use was attested only with the verb помочь ('help').
} 
and a deliminative may also refer to non-repeated situations. Furthermore, the idea of a repeated situation is part of many sentences with много in general, and also occurs in sentences without a delimitative verb. The delimitative perfective seems to be used in contexts where the idea of boundedness is emphasized, often in a context where the situation does not continue in the present, or in contexts with modal forms that usually occur with perfective infinitives, e.g., (99) and (100). The imperfective does not conceptualize the idea of boundedness, and can therefore easily occur with situations which are seen in their progression as in (101), or in the case of questions like (102), which have the character of the existential general factual use of the imperfective:

(101) Весь субботний день они много гуляли ${ }^{\mathrm{ipf}}$, плавали в бассейне, играли в теннис. (Л. Корнешов, Газета)

'The whole Sunday they walked ${ }^{\text {ipf }}$ a lot, swam in the pool, and played tennis.'

(102) Вы говорите, что много бродили ${ }^{\text {ipf }}$ по свету?

(Е. Шварц, Обыкновенное чудо)

'You tell me that you have wandered ${ }^{\mathrm{ipf}}$ a lot around the world?'

These delimitatives do, however, behave differently from regular perfective forms because they can denote ongoing processes. Note, for example that they can occur as the main clause of a sentence with пока не ('until'):

(103) Побродили ${ }^{\mathrm{pf}}$ по второму этажу, пока случайно не оказались в просторном помещении. (Столица, 1997.03.18)

'We wandered ${ }^{\mathrm{pf}}$ around the second floor, until by accident we came across a very large room.'

In sentences with пока не, the aspect of the verb in the main clause is usually imperfective, because the situation in the main clause is still in its progression when it is stopped by the situation mentioned in the subordinate clause. As is remarked by Xalizeva (1969), delimitatives form an exception to this rule.

Now, let us turn to the second type of delimitatives, namely verbs that express the idea of 'working'. The possibility of using a perfective with no- with these verbs was noticed by Bitextina (1975) with regard to example (92). Further examples are given in (104)-(106): ${ }^{17}$

(104) В тот день я много и успешно поработал ${ }^{\mathrm{pf}}[\ldots]$. (Октябрь, 2002)

'That day I worked ${ }^{\mathrm{pf}}$ a lot and with success.'

(105) Они оба много потрудились ${ }^{\mathrm{pf}}$ на этом поприще. (Поиск, 2003.09.12)

'They both worked ${ }^{\mathrm{pf}}$ a lot [lit. did a lot of work] in that field.'

(106) Много поработал ${ }^{\mathrm{pf}}$ Горский над русским Новым Заветом.

(Г. Флоровский, Пути русского богословия)

'Gorskij worked ${ }^{\text {pf }}$ a lot [lit. did a lot of work] on the Russian New Testament.'

${ }^{17}$ A similar use can also be found with много раз:

И еще много раз поработал ${ }^{\mathrm{pf}}$ подход Иона, когда требовалось провести инженерную экспресс-оценку выгодности того или иного технического решения, давая результаты часто нежданные.

(engine.aviaport.ru/issues/45/page24.html; 05-27-2008)

'And still many times Ion's approach worked ${ }^{\mathrm{pf}}$, when an engineer's profit-assessment of some technical question was required with haste, rendering oftentimes unexpected results.' 
Dickey (2006, 19-31) also discusses sentences with поработать and observes that they can occur with modifications like классно ('splendidly') or similar evaluative adverbs, which stress the success or positive effect of the realization of the situation. According to him, this use of nоработать cannot be seen as an actual or prototypical delimitative, but instead functions as regular perfective with a perfectum reading, where the effect of the realization of the situation is stressed. In the examples given (104)-(106) the idea of 'success' or 'effect' is present as well, explicitly at least in (104), and implicitly in (105) and (106). Although Dickey is right in pointing at the different status of this class of (semi-)delimitatives, a few remarks are in order.

First, it is not always easy to determine when one can speak of an actual or prototypical delimitative and when one should speak of a regular (or almost regular) perfective counterpart of an imperfective, as is shown in (104), where we find both a modification of quantity (duration), which is typical of regular delimitatives, and the adverb успешно ('successfully'), which seems typical of the special class of 'effect' delimitatives discussed by Dickey. Note, furthermore, that if we consider nоработать as a regular perfective counterpart of paбomams (see Dickey 2006, 26), we cannot easily account for the fact that only actual delimitatives and поработать/потрудиться can occur with много. Second, although Dickey $(2006,19)$ rightly states that поработать as well as потрудиться hardly ever occur with temporal adverbs when occurring with evaluative adverbs, counterexamples can be found on the Internet:

потрудиться

(107) Рабочие-кровельщики хорошо потрудились ${ }^{\mathrm{pf}}$ всю неделю.

(books.imhonet.ru/element/133447/)

'The roofers worked ${ }^{\mathrm{pf}}$ well the whole week.'

Dickey (2006, 19; footnote 10) also mentions a similar example and argues that it must be seen as a special instance, because the duration of the time expressed by the verb is shorter than the time expressed by the adverb. It is not fully clear to me, though, why this implies that such cases cannot be seen as counterexamples. Furthermore, in some sentences the time expressed by the adverb is fully occupied by the duration expressed by the verb:

(108) Каково же было мое удивление, когда через 15-20 мин давление ушло, и я отлично поработал ${ }^{\mathrm{pf}}$ весь оставшийся день. (www.pchelyak.narod.ru)

'You can imagine my astonishment, when after 15 to 20 minutes the pressure disappeared, and during the rest of the whole day, I worked ${ }^{\mathrm{pf}}$ splendidly.'

In my view, the data suggest that nоработаmь has indeed developed a strongly idiomatic meaning in combination with evaluative adverbs, and prototypically expresses the idea of a positive effect. However, the data suggest also that even with this meaning it does not function as a regular perfective, and still shows features of actual delimitatives. Furthermore, the possibility of using nотрудиться with много suggests that there is in fact a close relationship between the evaluative meaning of this verb and the idea of quantification. It may be that in the case of verbs that express 'working', the use of the perfective is typically associated with a result that can be conceptualized as quantitative. Interestingly, a similar phenomenon can be perceived in Dutch with the expression werk leveren ('deliver work'). This expression is used with evaluative adjectives like goed ('good'), and cannot be used without these evaluative expressions in most contexts. Compare (109) and (110). 
Table 5 Overview of aspect in the past tense

\begin{tabular}{|c|c|c|}
\hline & Meaning & Aspectual properties \\
\hline \multirow[t]{2}{*}{ иасто $\mathrm{X}$} & $\begin{array}{l}\text { - The distance between the } \\
\text { temporal intervals of a non- } \\
\text { specified number of situa- } \\
\text { tions X is small. }\end{array}$ & $\begin{array}{l}\text { Past tense: The imperfective is obligatory be- } \\
\text { cause nacmo refers to multiple non-specified sit- } \\
\text { uations. A perfective auxiliary is possible when } \\
\text { uacmo refers to the infinitive, and the perfective } \\
\text { expresses a state characterized by a period of } \\
\text { repeated situations }\end{array}$ \\
\hline & $\begin{array}{l}\text { - Secondary meaning: The } \\
\text { different situations occur in } \\
\text { a quick sequence. }\end{array}$ & $\begin{array}{l}\text { - Secondary meaning: The perfective past tense is } \\
\text { possible with delimitatives and inchoative per- } \\
\text { fectives derived from multiplicatives, because } \\
\text { the meaning of quick succession allows for } \\
\text { summarization. }\end{array}$ \\
\hline много раз $\mathrm{X}$ & $\begin{array}{l}\text { - The number of occurrences } \\
\text { of a situation } \mathrm{X} \text { is large. }\end{array}$ & $\begin{array}{l}\text { - Past tense: The imperfective is preferred because } \\
\text { the number of occurrences is large, which easily } \\
\text { suggests homogeneity. The perfective is possible } \\
\text { or preferred with some verbs that allow for a } \\
\text { summarization of the different occurrences into } \\
\text { a whole (typically in restrospective (perfectum) } \\
\text { contexts). }\end{array}$ \\
\hline много $\mathrm{X}$ & $\begin{array}{l}\text { - The situation } \mathrm{X} \text { is associ- } \\
\text { ated with a big quantity. }\end{array}$ & $\begin{array}{l}\text { - Past tense: The imperfective, because много ex- } \\
\text { presses a large quantity as a result of a long du- } \\
\text { ration or high frequency. The perfective is possi- } \\
\text { ble with delimitatives ( } \mathrm{no}^{-} \text {) and perfectives with } \\
\text { a quantitative prefix ( } \mathrm{Ha} \text {-) because they are both } \\
\text { associated with the idea of quantity. }\end{array}$ \\
\hline
\end{tabular}

(109) Je hebt gisteren goed werk geleverd.

'You did a great job [lit. have delivered good work] yesterday.'

(110) ? Je hebt gisteren werk geleverd.

'You did a job [lit. have delivered work] yesterday.'

This suggests that the idea of positive evaluation and the conceptualization of a situation as something quantifiable may be closely related. In sum, sentences with много usually occur with imperfective verbs, but the use of the perfective is possible, particularly with the prefixes $\mathrm{Ha}$ - and no-, which are each associated with the concept of quantification.

In Sect. 3, I have illustrated how the difference in meaning between иасто, много раз, and много is related to the aspectual use of these expressions. A general overview of the aspect in the past tense is given in Table 5 .

The overview in Table 5 shows that in the case of the past tense the verb is imperfective in most contexts. The perfective is, however, possible if the semantics associated with the expression of frequent repetition allows for the idea of 'summarization' of different situations. If we visualize the perfective aspect as a completed terminative situation that can be seen in its totality, as a whole, the effect of the interaction of the expression and the perfective aspect can be visualized in a simplified way, as in Figs. 4-6, where $x$ refers to the situation expressed by the verb in question. 
Figure 4 Perfective aspect with иасто

Figure 5 Perfective aspect with много раз
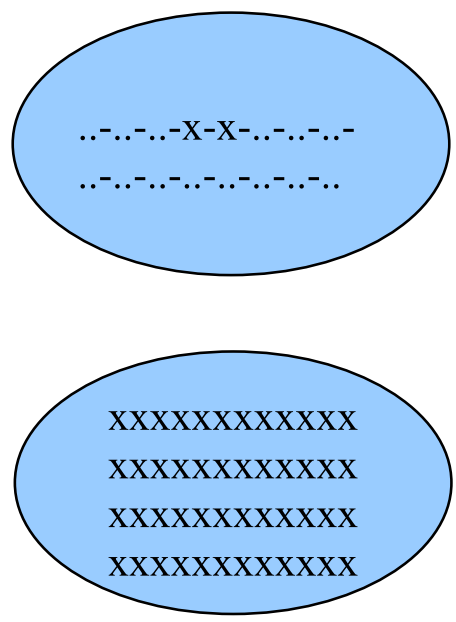

Figure 6 Perfective aspect with много

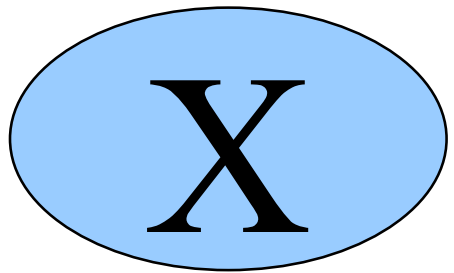

In the next section, I will further illustrate these differences in meaning by discussing a specific interpretational property of expressions of frequent repetition.

\section{Interpretational properties: the relational readings}

In this section, I will briefly discuss a specific interpretational property of expressions of frequent repetition, namely the possibility of the so-called relational use. The term '(non)relational' is used in the formally oriented semantic literature to refer to the property of expressions like often in English or souvent in French. These expressions can have two different interpretations if they occur with a subordinate clause with when or if (see for example de Swart 1991, 21). I will illustrate this with an English example, analogous to the example given in Doetjes (2007):

(111) When I go to Petersburg, I often visit the Russian Museum.

- Relational interpretation: Of the $n$ times that I visit Petersburg, relatively many times I go to the Russian Museum [implying that there are rare cases that I don't go there]

- Non-relational interpretation: In those cases that I go to Petersburg, I go relatively many times to the Russian Museum [implying that each time I go, I go back and forth to the museum all the time]

The difference between these readings is graphically illustrated in Figs. 7 and 8 .

As is remarked by Doetjes (2007, 705-708) operators like beaucoup ('a lot'), or trois fois ('three times') cannot get a relational reading. In her opinion this is due to the following 
Figure 7 Relational reading

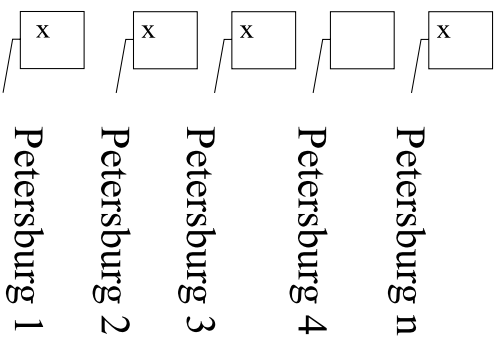

Figure 8 Non-relational reading

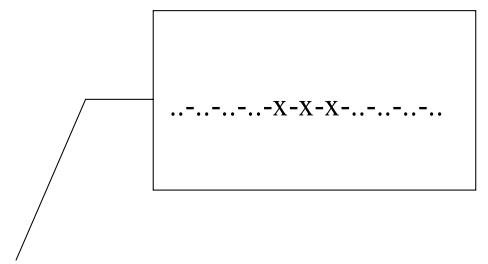

\section{Petersburg}

factors. First, in order to obtain a relational reading, the expression needs an anaphoric element, which can be identified by a when-clause. In the case of souvent this is the hidden 'time' operator. This excludes a relational reading with beaucoup. Second, a prerequisite for a relational reading is that the expression is compatible with a stative interpretation and a homogeneous predicate. This excludes the relational reading with trois fois, because this expression cannot be used with the imparfait in French. Since I have argued that uacmo, and its English and French counterparts often and souvent, cannot be paraphrased with 'many times', I will provide a somewhat different explanation for the possibility of a relational reading with Russian expressions of frequent repetition.

From the data at my disposal it can be concluded that uacmo can get a relational reading:

(112) После концерта, когда спрашивают, где найти Славу, Галина часто шутит: "Идите на звук поцелуев”. (С. Спивакова, Не всё)

'After the concert, when people ask me where they can find Slava, Galina often jokes: "Just follow the sound of the kisses".'

(113) Когда вокруг очень шумно, услышать речь из мобильного телефона часто бывает нелегко. (А. Андреев, Позитивные вибрации: телефон TS41 // Парадокс, 2004)

'When it is very noisy, it is often difficult to hear what people are saying through the cellphone.'

The data from the NKRJa and the internet show that in sentences with uacmo it is even rather difficult to obtain a non-relational reading. In order to arrive at such a reading, the main clause needs to express a large time span. Furthermore, the situation needs to be repeatable, which suggests that it must be terminative. This explains why it is not possible to get a non-relational reading with verbs like бblваmь, and why a non-relational reading is not fully excluded in the following sentence: 
(114) Просто когда быстро пишешь, часто допускаешь глупые, а порой неглупые ошибки.

(http://www.ren-tv.com/forum/index.php?showtopic=4733\&view=getnewpost; 05-27-2008)

'It's just that when you write quickly, you often [= many times?] make stupid and sometimes not so stupid mistakes.'

In my view, the reason why uacmo easily obtains a relational reading is because it expresses frequency, that is, repetition in abstraction from specific occurrences of a situation, and is consequently usually associated with a relatively large time span, or a time span with a generic character ('in general'). As such, it is comparable to редко, which, as I have shown earlier, even presupposes a larger time span. Because of this, the association between редко and a relational reading is even stronger:

(115) Даже когда видят покойников, редко признаются себе, что и им неизбежно придется лежать в гробу.

(www.nadesika.narod.ru/suicid_demon.htm; 05-27-2008)

'Even when they see dead people, they rarely acknowledge that they will end up in the grave as well.'

As such, иасто and редко differ from expressions that refer to different occurrences of a situation, which almost exclusively have a non-relational reading. This is the case with expressions of closed repetition (iteration), e.g., несколько раз and много раз:

(116) Честно говоря, когда мне клип не нравится, я его просто не смотрю. [...]

А если нравится, то много раз пересматриваю.

(glavred.info/archive/2006/08/11/164652-3.html; 05-27-2008)

'To be honest, when I don't like a video clip, I just don't watch it. But when I like it, I watch it many times.'

The restriction to non-relational readings is, however, not confined to expressions of closed repetition. It also occurs with the expression of open repetition время от времени ('from time to time') (cf. Doetjes 2007 for French de temps en temps):

(117) Даже если ребенок ни о чем не просит, приносите ему время от времени какую-нибудь маленькую приятную вещицу [...].

(http://adalin.mospsy.ru/1_03_00/10036.shtml; 05-27-2008)

'Even if the child doesn't ask for anything, bring him from time to time some nice little thing.'

As such время от времени differs from expressions such as иногда ('sometimes'), which normally yield a relational reading. The explanation for the non-relational reading of время от времени is probably that it more explicitly refers to the idea of an occurrence of a situation ('there are moments that $\mathrm{X}$ occurs, then it does not occur for some time, and then it occurs again, etc.'). The same property probably also explains that in contrast to иногда, время от времени is less easily associated with a generic meaning ('in general, there are occurrences of $X^{\prime}$ ), and shows more dependency with respect to the preceding context (see Molendijk and de Swart 1998 for an analysis of this feature with respect to French de temps en temps). 
Note that with много раз a relational reading is not fully excluded. This reading occurs if the expression occurs at the beginning of the sentence, where it has scope over the whole sentence:

(118) Много раз, когда я говорю как сейчас, это сказано саркастическим тоном. (accords.com.ua/news/Nirvana/1490; 05-27-2008)

'Many times, when I speak like this, it is said in a sarcastic way.'

In this sentence, много раз does not modify the predicate of the main clause ('say something many times in a sarcastic way'), but has scope over the entire sentence ('many of the times when I speak like this'). Here a relational reading is probably made possible by two semantic properties of много раз. First, although много раз is an expression of closed repetition, it expresses an indefinite number of iterated situations. As such, its meaning differs from sentences with modifiers like три раза, which can never obtain a relational reading. Second, in the case of много раз the repetition of an indefinite number of situations is frequent, which probably makes it easier to get a relational reading than in the case of expressions like несколько раз. Why these two properties facilitate a relational reading is a topic that deserves a separate analysis.

Finally, sentences with много cannot yield a relational reading:

(119) Дедушка Платон в доме бывает мало, он много работает, а когда приходитмного спит, потому что устает.

(zhurnal.lib.ru/s/sonechka_1/plushka.shtml; 05-27-2008)

'Uncle Platon rarely comes to our house, he works a lot, and when he comes, he sleeps a lot, because he is tired.'

The explanation is that много does not inherently have a temporal meaning, but refers to a quantity, and, in the case of different situations, quantifies the situations it is applied to, conceptualizing them as one collection of events (cf. the analysis of Doetjes 2007 for French beaucoup).

To conclude, the relational interpretation occurs with expressions such as uacmo or редко because they do not refer to specific occurrences of an event, but abstract over specific occurrences, thereby suggesting a (homogeneous) state. As such, they differ from expressions of closed repetition, including много раз, which almost exclusively refer to repeated situations in a particular time interval. Finally, много always has a non-relational reading because it is not inherently temporal, and therefore refers to one event or summarizes different events within one specific time interval.

\section{Conclusion}

In this paper, I have given an analysis of three forms in Russian that can express frequent repetition: иасто, много раз аnd много. Although these expressions seem to have quite similar meanings at first sight, closer inspection reveals a number of interesting differences. As such, my analysis differs from analyses that define the meaning of uacmo as "many times' (see Doetjes 2007).

The adverb nacmo expresses that the distance between different non-specified temporal intervals is small according to some contextually given norm. The expression $4 a$ cmo abstracts away from, and therefore does not specify, the exact number of occurrences of the situation. Because of this it usually refers to occurrences that take place 
in a relatively large time span, or a non-specified time span ('in general'), and has a typical frequency character. This specific feature explains why the use of the present tense rather than the past tense is typical for nacmo. However, by using specific temporal modifications, the repetition may also refer to situations that take place in a relatively short time, such as a day or an hour. Furthermore, in sentences with multiplicative verbs and in sentences with an ingressive auxiliary (начинать), иасто may also refer to different situations that occur quickly in a row ('quickly', 'one after the other', etc.).

I have shown that because uacmo abstracts away from specific occurrences of a situation, it is typically used with imperfective verbs, even if the verb itself is associated with the idea of a boundary (terminus, telos). This is because the repetition of a non-specified number of situations makes it difficult to conceptualize the collections of repeated events into one whole. The correlation with the imperfective is especially strong in the case of the past tense. However, in the past tense, the perfective is possible with a number of past tense auxiliaries, if nacmo is applied to the infinitive. The perfective past tense is also possible if nacmo expresses 'in a quick succession', and the past tense verb is derived from a multiplicative by adding an inchoative ( $3 a-)$ or delimitative (no-) prefix.

The expression много раз also expresses a large number of repeated situations, but unlike nacmo it does not fully abstract away from the idea of an individual occurrence. As such, it cannot be seen as a frequency expression, but rather expresses iteration. This explains why it is typically used in combination with past tense verbs, where the identity of specific occurrences of the situation is established. Furthermore, unlike nacmo it can more easily be used in the case of situations that occur in a relatively short time span. Like иасто, много раз is typically used with imperfective verbs, because the large repetition of situations suggests the idea of a homogeneous state. However, because it expresses different specific events, it is possible to summarize the different events into one whole by using the perfective. In this paper I have discussed different factors that may trigger the perfective. Although these factors are to a large extent similar to factors that trigger the perfective in the case of other expressions of closed repetition, there are also interesting differences.

The quantifier много primarily expresses the idea of a large quantity. It can be interpreted as referring to a large number of repeated situations, but this is a secondary meaning, and not an inherent part of the meaning of много. The specific semantic feature of 'quantity' was illustrated with the different verbs with which много is used. These verbs are all typically associated with a particular quantity. As such, the use of много differs from the other two expressions of frequent repetition. The aspect of verbs that occur with много is almost exclusively imperfective, with the exception of verbs with a delimitative (no-) or quantitative ( $\mathrm{Ha}$-) prefix. In both cases, the use of the prefix is closely connected to the quantitative meaning of много.

I have illustrated the differences in meaning between the frequency expressions particularly with respect to aspect. However, I have also briefly discussed some other interpretational properties, more specifically the occurrence of so-called relational readings. As I have shown, only uacmo can easily obtain a relational reading because it abstracts away from the idea of a specific occurrence of a situation. Such a reading is not easily triggered by много раз, which refers to a large number of specific occurrences of a situation. In the case of много, a relational reading is excluded altogether, which stresses that its basic meaning is not temporal.

My discussion suggests that although many of the properties of the expressions of high frequency are based on general semantic properties which are valid cross-linguistically, 
there are also important language specific properties. A good example is the use of uacmo in its use of 'in a quick succession'. This use is absent in languages such as English or Dutch. Furthermore, the data from Russian suggest, that Russian often uses uacmo, where English uses other expressions, for example regularly or frequently. Further research could therefore focus on a cross-linguistic comparison of these expressions. Furthermore, as is well known from the literature (e.g., Dickey 2000), aspect in Russian behaves differently from aspect in other Slavic languages. It would therefore be interesting to investigate to what extent there are differences and similarities between the use of aspect in the case of expressions of high frequency in Russian and other Slavic languages.

Open Access This article is distributed under the terms of the Creative Commons Attribution Noncommercial License which permits any noncommercial use, distribution, and reproduction in any medium, provided the original author(s) and source are credited.

\section{Appendix A: Verbs attested with uacmo in 100 randomly collected sentences from the NKRJa}

\begin{tabular}{|c|c|c|}
\hline Verbs & Frequency & Total \\
\hline 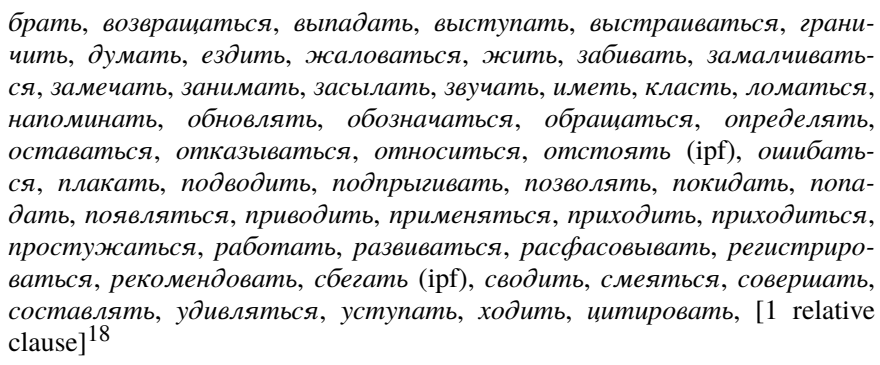 & 1 & 56 \\
\hline $\begin{array}{l}\text { играть, использовать }(\text { ся }), \text { можно }(+\mathrm{pf}), \text { мочь, наблюдаться, } \\
\text { сопровождаться, сльшать, удаваться, употреблять }\end{array}$ & 2 & 18 \\
\hline делать, менять (ся) & 4 & 8 \\
\hline встречаться & 5 & 5 \\
\hline past passive participle & 6 & 6 \\
\hline бывать & 7 & 7 \\
\hline Total & & 100 \\
\hline
\end{tabular}

\footnotetext{
${ }^{18}$ This refers to the following sentence:
}

[Р]оль главного эксперта перешла к читателю, который и выносит “приговор” автору-часто под влиянием рекламных кампаний [...]. (Октябрь, № 7, 2003)

'The reader has taken over the role of the main expert, and 'sentences' the author, often influenced by advertising campaigns.'

In this sentence uacmo refers to the preceding clause, and has a reading which closely resembles the socalled relational reading (see Sect. 4): "when a reader sentences the author, it is often the case that he is influenced by advertising campaigns'. 


\section{Appendix B: Verbs attested with много раз in 100 randomly collected sentences from the NKRJa ${ }^{19}$}

\begin{tabular}{|c|c|c|}
\hline Verbs & Frequency & Total \\
\hline $\begin{array}{l}\text { бывать, вешали, встречаться, входить, выезжать, гастролировать, } \\
\text { дарить, доводиться (+ infinitive), ездить, жаждать, жалеть, за- } \\
\text { ступаться, звонить, играть, наказывать, наступать, облануть (pf), } \\
\text { объясняться, оказываться, откладываться, открываться, ошибаться, } \\
\text { переделывать, переиздаваться, переходить, перечитывать, петь, } \\
\text { печататься, подмьвать, пользоваться, помогать, понести (pf), по- } \\
\text { рываться, править, признавать, просить, просыпаться, публиковать- } \\
\text { ся, рассказывать, разговавить, репетировать, рисовать, ронять, се- } \\
\text { товать, слушать, слотреть, сниться, собраться (pf), согласовывать, } \\
\text { спрашивать, сталкиваться, убеждаться, ульбнуться (pf), уиаство- } \\
\text { вать, хоронить, хотеть (+ рf), цитироваться }\end{array}$ & 1 & 57 \\
\hline $\begin{array}{l}\text { видеть, взывать, обрашаться, предлагать, приходиться (+ infinitive), } \\
\text { сльшиать, умереть (иуть не) (мог бы) }(+\mathrm{pf})\end{array}$ & 2 & 14 \\
\hline пьлтаться, $[$ быть + past participle $]$ & 3 & 6 \\
\hline делать(ся), писать(ся), повторять(ся), приходить & 4 & 16 \\
\hline говорить (ся) & 9 & 9 \\
\hline
\end{tabular}

\section{Appendix C: Verbs attested with много in 100 randomly collected sentences from the NKRJa ${ }^{20}$}

\begin{tabular}{|c|c|c|}
\hline Verbs & Frequency & Total \\
\hline $\begin{array}{l}\text { анализировать, атаковать, выступать, беседовать, бродить, гово- } \\
\text { риться, дежурить, дискутировать, заморачиваться, играть, изучать, } \\
\text { напетлять (рf), нервничать, падать, переезжать, перемешаться, петь, } \\
\text { плавать, помогать, простегивать, путешествовать, радоваться, разъ- } \\
\text { езжать, рекламировать, рисовать, сидеть, сльшать, смотреть, спать, } \\
\text { страдать, стрелять, толковать, трепаться, убивать, философство- } \\
\text { вать, иариться, иутить }\end{array}$ & 1 & 37 \\
\hline $\begin{array}{l}\text { говорить, ездить, плакать, забивать, жаловаться, спорить, иело- } \\
\text { вать(ся) }\end{array}$ & 2 & 14 \\
\hline болеть, курить, общаться & 3 & 9 \\
\hline размышлять, смеяться, трудиться & 4 & 12 \\
\hline думать & 6 & 6 \\
\hline заниматься & 10 & 10 \\
\hline работать & 16 & 16 \\
\hline Total & & 104 \\
\hline
\end{tabular}

\footnotetext{
${ }^{19} 2$ sentences with 2 verbs.

204 sentences with 2 verbs.
} 


\section{References}

Barentsen, A. A. (1992). Ob obstojatel'stvax ograničennoj kratnosti dejstvija v russkom jazyke, čast' 1. In A. A. Barentsen et al. (Eds.), Studies in Russian linguistics (Studies in Slavic and General Linguistics, 19) (pp. 1-66). Amsterdam.

Barentsen, A. A. (1994). Ob obstojatel'stvax ograničennoj kratnosti dejstvija v russkom jazyke, čast' 2 . In A. A. Barentsen et al. (Eds.), Dutch contributions to the eleventh International Congress of Slavists, Bratislava, August 30-September 9, 1993. Linguistics (Studies in Slavic and General Linguistics, 22) (pp. 1-50). Amsterdam.

Barentsen, A. A. (1995). Trexstupenčataja model' invarianta soveršennogo vida v russkom jazyke. In S. Karoljak (Ed.), Semantika i struktura slavjanskogo glagol'nogo vida I (pp. 1-26). Kraków.

Barentsen, A. A. (1997). Rol' leksičeskogo značenija glagola pri vybore vida v kontekste ograničennoj kratnosti. In S. Karoljak (Ed.), Semantika i struktura slavjanskogo glagol'nogo vida II (pp. 7-30). Kraków.

Bitextina, G. A. (1975). Ob upotreblenii količestvennyx narečij očen' i mnogo. Russkij jazyk za rubežom, 1, 66-68.

Bondarko, A. V. (1971). Vid i vremja russkogo glagola. Značenie i upotreblenie. Moskva.

Dickey, S. (2000). Parameters of Slavic aspect. A cognitive approach. Stanford.

Dickey, S. (2006). Aspectual pairs, goal orientation and PO-delimitatives in Russian. Glossos, 7 , http://www.seelrc.org/glossos/issues/7/dickey.pdf (05-27-2008).

Doetjes, J. (2007). Adverbs and quantification: degrees versus frequency. Lingua, 117(4), 685-720.

Fortuin, E. (to appear). The construction of degree in Russian. In J. Schaeken et al. (Eds.), Dutch contributions to the fourteenth International Congress of Slavists, Ohrid (Studies in Slavic and General Linguistics, 34). Amsterdam.

Kučera, H., \& Trnka, K. (1975). Time in language. Temporal adverbial constructions in Czech, Russian and English. Michigan.

Maslov, Ju. S. (1948). Vid i leksičeskoe značenie glagola v sovremennom russkom literaturnom jazyke. Izvestija AN SSSR, otdelenie literatury i jazyka, 7(4), 303-316.

Mehlig, H. R. (1982). Verbalaspekt und Iteration im Russischen. Zum Aspektgebrauch bei Referenz auf mehrmalige Ereignisse. In W. Girke (Ed.), Slavistische Linguistik 1981. Referate des VII. Konstanzer Slavistischen Arbeitstreffens, Mainz 30.9.-2.10.1981 (Slavistische Beiträge, 160) (pp. 113154). München.

Mehlig, H. R. (2008). Aspect and bounded quantity complements in Russian. In S. Rothstein (Ed.), Theoretical and crosslinguistic approaches to the semantics of aspect (Linguistik Aktuell/Linguistics Today, 110) (pp. 257-290). Amsterdam, Philadelphia.

Melig, X. R. (2006). Glagol'nyj vid i vtoričnaja gomogenizacija oboznačaemoj situacii posredstvom kvantifikacii: k upotrebleniju deliminativnogo sposoba dejstvija v russkom jazyke. In F. Leman (Ed.), Glagol'nyj vid i leksikografija. Semantika i struktura slavjanskogo vida IV (Slavolinguistica, 7) (pp. 235-276). München.

Molendijk, A., \& de Swart, H. (1998). Frequency and tense use in French. In S. Vogeleer et al. (Eds.), Tense and aspect. The contextual processing of semantic indeterminacy (Belgian Journal of Linguistics, 12) (pp. 43-60). Amsterdam, Philadelphia.

Petruxina, E. V. (2000). Aspektual'nye kategorii glagola v russkom jazyke v sopostavlenii s češskim, slovackim, pol'skim i bolgarskim jazykami. Moskva.

Sémon, J.-P. (1979). L'acte itératif nombré et l'aspect. IIe Colloque de linguistique Russe, Paris 22-24 avril 1977 (pp. 87-104). Paris.

Sémon, J.-P. (1986). Postojat' ou la perfectivité de congruence: définition et valeurs textuelles. Revue des Études Slaves, 58, 609-635.

de Swart, H. (1991). Adverbs and quantification: a generalized quantifier approach. Ph.D. dissertation, University of Groningen.

Xalizeva, V. S. (1969). Semantičeskij analiz sojuzov predšestvovanija. Russkij jazyk za rubežom, 2, 77-82. 